Board of Governors of the Federal Reserve System

International Finance Discussion Papers

Number 612

May 1998

MONETARY SHOCKS AND REAL EXCHANGE RATES

John H. Rogers

NOTE: International Finance Discussion Papers are preliminary materials circulated to stimulate discussion and critical comment. References in publications to International Finance Discussion Papers (other than an acknowledgment that the writer has had access to unpublished material) should be cleared with the author or authors. Recent IFDPs are available on the Web at www.bog.frb.fed.us. 


\title{
MONETARY SHOCKS AND REAL EXCHANGE RATES
}

\author{
John H. Rogers*
}

\begin{abstract}
Many explanations of the stylized facts concerning real exchange rate movements focus on monetary shocks, but it is often found empirically that monetary shocks are unimportant. I provide evidence that is contrary to this empirical finding. Using over 100 years of data, I estimate the contribution of various shocks to explaining variation in the real pound-dollar exchange rate. Monetary shocks consist of both monetary base and money multiplier shocks; real shocks include fiscal, productivity, and preference shocks. Estimates of several alternative VAR specifications provide a range for the contribution of the various shocks: from 19 to 60 percent in the short-run for monetary shocks and 4 to 26 percent for fiscal and productivity shocks combined. My modeling strategy and results are compared directly to related work. The results lend empirical support to the convention in recent quantitative general equilibrium modeling of focusing on monetary shocks.
\end{abstract}

Keywords: exchange rates, monetary shocks, vector autoregressions

\footnotetext{
*The author is an economist in the International Finance Division of the Federal Reserve Board. He thanks Shaghil Ahmed, David Bowman, and Jon Faust for many useful conversations, Michael Sharkey for useful research assistance, and seminar participants at Harvard, Michigan, and Michigan State for their feedback. The views in this paper are solely the responsibility of the author and should not be interpreted as reflecting the views of the Board of Governors of the Federal Reserve System or of any other person associated with the Federal Reserve System.
} 
This paper takes up the question: what is the nature of the shocks that drive the real exchange rate? There are several reasons to care about the answer to this question. First, it is relevant for policy makers. Suppose that real shocks, as opposed to monetary shocks, were found to be the dominant influence. This would inform policy makers that a flexible exchange rate system is preferable to fixed rates, or at the very least would highlight an important potential drawback associated with maintaining a system of fixed exchange rates.

Second, evidence on this question is relevant for the literature on dynamic stochastic general equilibrium models of the real exchange rate. Recent work including Obstfeld and Rogoff (1995), Beaudry and Devereux (1995), Chari, Kehoe, and McGrattan (1996), and Atkeson and Kehoe (1997) focuses exclusively on the effects of monetary shocks. For example, Chari, Kehoe, and McGrattan (1996) ask whether a general equilibrium model with sticky prices and imperfect competition can replicate the observed pattern of real exchange rate persistence following monetary shocks. Atkeson and Kehoe (1997) examine a model in which both asset markets and goods markets are segmented, focusing exclusively on the effects of monetary shocks on international relative price movements.

By focusing on monetary shocks to flesh out the implications of various modeling structures, these papers address important and interesting controversies in the theoretical literature. In addition, the focus on monetary shocks follows conventional wisdom: concerning the well-known result of Mussa (1986) that real and nominal exchange rate volatility is roughly equal, Chari, Kehoe and McGrattan (1996,pg.1) note:

"The conventional wisdom is that these observations are the result of monetary shocks and they can best be understood in a model with sticky prices."

Although this quote likely reflects the conventional wisdom, the empirical literature has yet to uncover much direct evidence that monetary shocks are important for real exchange rate determination. ${ }^{1}$

\footnotetext{
${ }^{1}$ The literature has provided indirect evidence on the nature of the shocks that drive the real exchange rate. Several early papers linked statistical evidence on real exchange rates, nominal exchange rates, prices, and other macroeconomic variables with theoretical models of the exchange rate, and discussed what this implied about the nature of the shocks that drive the real exchange rate [see Stockman (1983),
} 
Papers that have attempted to directly identify various shocks to the real exchange rate and compare their relative magnitudes often find that monetary shocks are unimportant. For example, Clarida and Gali (1994) use Blanchard-Quah (1989) style vector autoregressions (VARs) to estimate the relative contribution of various shocks to several U.S. dollar real exchange rates during the post-Bretton Woods era. They find that nominal shocks account for no more than $2.8 \%$ of the variance of real exchange rate changes over all horizons for the United Kingdom, the country I focus on in this paper. The contribution is larger in the cases of Germany and Japan, but even smaller in the Canadian case. Eichenbaum and Evans (1995) estimate VARs with contemporaneous identification restrictions, and report for three different model specifications the contribution of monetary policy shocks to the variance of several U.S. dollar real exchange rates. For the United Kingdom, the mean contribution of the monetary policy shock across the three specifications is $17 \%^{2}$

The evidence I present in this paper indicates that, to the contrary, monetary shocks are typically very important for real exchange rate movements. Using the structural VAR framework of Blanchard and Quah (1989), I identify various types of shocks in over 100 years of data from the United States and

and Mussa (1986)]. More recent studies examine the statistical link between real exchange rates and real interest rates [Campbell and Clarida (1987), Meese and Rogoff (1988), Edison and Pauls (1993), and Baxter (1994)], or the time-series properties of real exchange rates, nominal exchange rates, and relative prices [Frankel (1986), Edison (1987), Mark (1990), Diebold, Husted, and Rush (1991), and Rogers and Jenkins (1995)]. These papers assess the validity of different explanations for deviations from the law of one price, as do Engel (1993) and Engel and Rogers (1996).

${ }^{2}$ The standard error is 11.0 on average across the three specifications. Standard errors of a similar magnitude -- relative to point estimates - are found in related VAR studies. The average contribution of the monetary shock to explaining nominal pound-dollar exchange rate variability is $13 \%$, with a standard error of 9.0. They report the average contribution over the 31-36 month horizon. Two other papers undertake a similar analysis, but don't examine the United Kingdom. Lastrapes (1992) estimates a Blanchard-Quah style VAR in the nominal and real exchange rates for Canada, Germany, Italy, and Japan, and finds an impact contribution of the nominal shock as low as $6 \%$ for Canada. Enders and Lee (1997) estimate Blanchard-Quah style VARs in output, government spending, M1, and the real exchange rate for the U.S. versus Canada, Germany, and Japan. The maximum contribution of the monetary shock to explaining variation in the real exchange rate is $4.8 \%$ at the 2-quarter horizon for Japan. 
United Kingdom. ${ }^{3}$ Forecast error variance decompositions (VDC) indicate that real shocks and monetary shocks, the latter of which are restricted to having zero effect on the levels of real variables in the long run, account for approximately the same percentage of the variance of the real exchange rate over short horizons. I decompose the real and monetary shocks into fiscal, supply (or productivity), and demand (or preference) shocks, and money multiplier and monetary base shocks, in order to assess the nature of those broadly-defined shocks.

I then examine the robustness of my results to alternative definitions of the real exchange rate and to several alternative model specifications. The robustness checks provide a range of estimates for the contribution of the various shocks. For example, I find that the short-horizon contribution of monetary shocks ranges from $18.7 \%$ to $60.2 \%$, with a median contribution of $40.6 \%$. The combined effect of fiscal and productivity shocks over the same horizon ranges from $4.3 \%$ to $25.6 \%$. By providing a range for the estimated contribution of money shocks, I take my VAR analysis a small step in the direction recently advocated by Faust (1998).

Although my finding that "both real and monetary shocks matter" may come as no surprise to those who hold the prior belief that "many shocks are probably important", my results are distinct from what is typically found in the literature. Furthermore, my result that monetary shocks matter (more than what has been found elsewhere) indicates that the focus on monetary shocks in the recent dynamic general equilibrium literature is well-founded empirically as well as theoretically. A natural question that then arises is, why are my results different from existing ones? To find out, I undertake an "encompassing style analysis" in the final section of the paper, estimating the Clarida-Gali model with my data sample and my model with the Clarida-Gali sample. This analysis indicates that the choice of model is more important than the sample period for explaining differences in our results.

${ }^{3}$ I focus on the long-term pound/dollar exchange rate because for these countries a long uninterrupted span of macroeconomic data is available. This is desirable on both statistical and economic grounds. 


\section{The Data}

I use annual observations from the United Kingdom and United States on exchange rates, prices, GNP, M2, the monetary base, and government spending. The data runs from 1889, the earliest availability of the U.S. GNP components, to 1992, when important changes in definition were made in several series, especially U.K. M2. ${ }^{4}$ The sources for the data on prices, output, and government spending are Mitchell (1988) for the United Kingdom and Kendrick (1961) for the United States. The exchange rate series is also taken from Mitchell (1988), while the money supply and monetary base data are taken from Friedman and Schwartz (1982). Updates are from Britain's Central Statistical Office, and various issues of the Survey of Current Business for the United States.

Figure 1 contains plots of the series (in levels) used in the VAR. The transformed variables used in the VAR are ( $\Delta$ denotes the first-difference operator $)^{5}$ :

$\Delta(\mathrm{G} / \mathrm{Y})=$ real government consumption as a share of real GNP, U.K. less U.S.; $\Delta \mathrm{y}=\log$ of real GNP, U.K. less U.S. (annual average.); $\Delta \mathrm{r}=\log$ of real exchange rate $=\Delta(\mathrm{S}-\mathrm{P})$, where

$\mathrm{S}=\log$ of the nominal exchange rate in pounds per dollar

$\mathrm{P}=\log$ of the wholesale price index, U.K. relative to U.S.;

$\Delta \mathrm{mm}=\log$ of money multiplier, $\Delta \log (\mathrm{M} / \mathrm{H})$, U.K. less U.S., where

$\mathrm{M}=$ nominal $\mathrm{M} 2$ money stock (mid-year observation)

$\mathrm{H}=$ nominal monetary base (mid-year observation);

$\Delta \mathrm{h}=\log$ of real monetary base, $\Delta \log \left(\mathrm{H} / \mathrm{P}_{\mathrm{N}}\right)$, U.K. less U.S., where

$\mathrm{P}_{\mathrm{N}}=$ price of non-traded goods, as proxied by the government expenditure deflator.

${ }^{4}$ U.K. M2 totaled 275 million pounds in November 1992 (essentially unchanged from its level at the start of the year), but as result of a change in definition rose to 372 million in December, a 48 percent "permanent" jump. Because of this and two recent changes that affect the U.S. data -- the practice of reporting data in "chain-weighted" dollars and the change in the way the components of U.S. government expenditures are treated -- updating the data consistently beyond 1992 was problematic.

${ }^{5}$ I also check robustness to two alternative measures of the real exchange rate. The first, labeled $\mathrm{r} 2$, is constructed with GNP price deflators instead of wholesale price indexes. The second alternate measure, $\mathrm{r} 3$, is the log-ratio of the government expenditure deflator to the GNP deflator (U.K. less U.S.), and is thus a crude proxy for the relative price of non-tradeables. Note that CPI data do not exist prior to 1914. 
Notice that initially I estimate a VAR in first-differences. Tests for unit roots and cointegration support this specification, but also indicate that some of the results are borderline. In light of Faust and Leeper's (1997) critique, discussed at length below, this suggests that I also estimate alternative specifications.

Unit roots test results are reported in table 1. For the real exchange rate series, these indicate a failure to reject the unit root null hypothesis of the Augmented Dickey-Fuller (ADF) test, and a rejection of the trend-stationary null in the case of the Kwiatowski, Phillips, Schmidt, and Shen (KPSS) test. ${ }^{6}$ This is true of each of the three real exchange rate measures, and for tests with either a lag length of 5 or a lag length determined by the Akaike Information Criterion (AIC). The same results, failure to reject the ADF null and rejection of the KPSS null, are obtained for output (y) and the money multiplier (mm). For the other two variables in the VAR, however, inference is mixed: for $(\mathrm{G} / \mathrm{Y})$, the ADF test rejects the unit root null, while the KPSS test using the AIC-based lag length rejects the trend-stationary null at $10 \%$; for the monetary base (h), both ADF and KPSS tests fail to reject their respective null hypotheses.

Likelihood ratio (LR) tests for lag length in the VAR containing $(\mathrm{G} / \mathrm{Y}), \mathrm{y}, \mathrm{rl}, \mathrm{mm}$, and $\mathrm{h}$ are presented in table 2. The $\chi^{2}(25)$ test statistic comparing the 8-lag model to the 7-lag model is 39.4, indicating a rejection of the null that lags 8 are zero at the $3 \%$ level. The test for the 5-lag VAR versus the 4-lag VAR rejects at $6 \%$, while that for 2 lags versus 1 lag rejects at less than $1 \%$. None of the other tests, including 8 lags versus 5 lags, produces a rejection at less that $18 \%$.

Johansen (1991) tests for the number of cointegration vectors in the system $\{(\mathrm{G} / \mathrm{Y}), \mathrm{y}, \mathrm{r} 1, \mathrm{~mm}$, and $\mathrm{h}$ \} are contained in table 3. In light of the LR tests of table 2, I report results for lag lengths 2, 5, and 8. According to both the maximum-eigenvalue test and the trace test, and for all lag lengths, the null of zero cointegration vectors cannot be rejected. The results suggest estimating the VARs using a firstdifference specification without imposing any cointegration relationships.

${ }^{6}$ In their critique of structural VARs, Faust and Leeper (1997, section 2.2) recommend testing both the unit root null and the trend-stationary null. I discuss this in more detail below. 
Exclusive reliance on the unit roots test results listed in table 1 may be unwise. Some of the results are borderline. ${ }^{7}$ Furthermore, several authors have argued that as an empirical matter it is impossible to distinguish between an I(0) and an I(1) series in any finite sample [Blough (1992), Faust (1995)]. Although Froot and Rogoff (1995) describe an emerging consensus concerning mean reversion of real exchange rates, Engel (1996) argues that tests on long-term real exchange rate data have tended to over-reject the unit root null, since there are serious size distortions in tests on a random variable such as this one that may contain a stationary but persistent component and a non-stationary component. O'Connell (1996) has cast doubt on evidence of mean reversion in panel data.

Given the current state of the literature on unit roots in real exchange rates, it seems like a reasonable strategy to consider alternative cases in the VAR section: some assuming that the real exchange rate is $\mathrm{I}(1)$, and others assuming it is $\mathrm{I}(0)$. I also consider VARs in which $(\mathrm{G} / \mathrm{Y})$ is assumed to be stationary. Estimating the VAR with the real exchange rate in first differences, as in Clarida and Gali (1994), allows certain shocks to have permanent effects on the level of the real exchange rate. This is consistent with the literature suggesting that technology shocks and demand shocks such as government spending can have permanent effects (see Froot and Rogoff (1995), section 3). On the other hand, estimating the VAR with the real exchange rate in levels is more consistent with evidence finding stationarity in long-term real exchange rate data [Frankel (1986), Edison (1987), Diebold, Husted, and Rush (1991), and one case in Mark (1997)] . However, stationarity implies that no shocks can have a permanent effect on the level of the real exchange rate. These considerations bring up important identification issues that I address in section 2.

${ }^{7}$ For example, as reported in Rogers (1995), the $\operatorname{ADF}(\tau)$ statistic for $\mathrm{r} 1$ when the sample period includes the 30 years prior to 1889 is -3.49 , which rejects the unit root null at $5 \%$. Also, note that if we use the BIC to select lag length, the KPSS test rejects trend-stationarity in $\mathrm{h}$ at $1 \%$, again contradicting the results reported in table 1 . The uncertainty surrounding the ADF test results is perhaps most evident in the 95\% confidence intervals for the largest autoregressive root, calculated using Stock's (1991) procedure. As reported in parenthesis in table 1, these intervals all contain 1.00 but also values well below 1. In his analysis of the long-term pound-dollar real exchange rate, Mark (1997, section 1.1) reaches very much the same conclusion as I do. 


\section{Identification and Derivation of the Structural Vector Autoregression Model}

In this section I estimate small-scale macro models that include the real exchange rate and fiscal and monetary variables. I begin by briefly discussing the econometric procedure and some critiques of it, then give a justification for interpreting the structural shocks of my model. Several alternative cases are considered for robustness.

\section{The Long-Run Identification Scheme}

Consider a vector of stationary variables $\mathrm{X}$ and a vector of structural disturbances $\epsilon$. The structural model can be compactly written,

$$
\mathrm{X}_{\mathrm{t}}=\mathrm{C}(\mathrm{L}) \epsilon_{\mathrm{t}}
$$

where $\mathrm{C}$ is a non-singular matrix of coefficients, and $\mathrm{L}$ denotes the lag operator. A reduced form of the structural system that can be estimated is given by,

$$
\Gamma(\mathrm{L}) \Delta \mathrm{X}_{\mathrm{t}}=\Phi \mathrm{X}_{\mathrm{t}-1}+\epsilon_{\mathrm{t}}^{*}
$$

If $\mathrm{X}$ contains $\mathrm{n}$ elements, identification requires choosing $\mathrm{n}(\mathrm{n}-1) / 2$ elements of the long-run moving average coefficient matrix, $\mathrm{C}(1)$ (after normalizing the shocks and making the assumption that the structural disturbances are mutually uncorrelated). The particular zero restrictions used in this paper to achieve identification are reflected in equation (3) below. Under this procedure, also used by Ahmed, Ickes, Wang, and Yoo (1993) to retrieve the structural coefficients from the reduced form, C(1) is identified up to the sign of its diagonal elements. The method of identification imposes no restrictions on the short-run movements of the variables.

Before turning to the estimation, it is worthwhile discussing some of the critiques of this empirical approach. Lippi and Reichlin (1993) note that it must be assumed that the MA representation is fundamental, since otherwise the structural VAR methodology would be improper. Blanchard and Quah (1993) and Faust and Leeper (1997) emphasize that this assumption is required in standard macroeconometric work and is made implicitly in most time-series empirical studies. In other words, ruling out nonfundamental MA representations is common in practice. 
Faust and Leeper (1997) make two criticisms that are potentially relevant to my paper, questioning the validity of both imposing the long-run restrictions on $\mathrm{C}(1)$ and the implicit aggregation of shocks found in many applications. Both concerns motivate my robustness checks.

The former concern corresponds to Faust and Leeper's criticism \#1. The gist of the criticism is that, because I impose infinite order (long-run) restrictions on a finite order VAR, the estimation results are correct only if the estimated reduced-form VAR is the correct representation. Faust and Leeper (section 2.2) offer two simple suggestions to deal with this problem. First, test the null of trendstationarity for any of the variables assumed to have unit roots. This can highlight the uncertainty about the maintained hypothesis that there are permanent effects on a variable. Second, if one rejects trendstationarity for those variables required to have unit roots, identify the VAR under other restrictions and see how close the long-run restriction comes to holding. Faust and Leeper note that, although their suggestions are ad hoc approaches to dealing with the problems they bring up, such evidence provides a counter-balance to results obtained with the typically-maintained hypotheses of the Blanchard-Quah scheme. I follow both of Faust and Leeper's suggestions, and demonstrate that their criticism is empirically important in some cases.

The second concern elaborated upon by Faust and Leeper (1997) is that, if one identified structural shock consists of two independent shocks, then the Blanchard-Quah methodology is valid only if the underlying macroeconomic variables respond to the two shocks in the same directions. Because many theoretical models suggest that fiscal and output shocks lead to opposite effects on the real exchange rate, I estimate models which separate the two. Of course, an "output" shock may consist of both demand and supply shocks, and a "monetary" shock may contain both money demand and money supply shocks (or shocks to inside money as well as to outside money). These disaggregated shocks may affect the real exchange rate differently. As a consequence, I decompose the monetary shock into monetary base and money multiplier shocks, under the assumption that exogenous changes in the monetary base have a one-to-one effect on the money supply in the long-run. In addition, I identify a 
"preference" or "demand" shock separately from the output "supply" shock, based on the assumption that output is supply-determined in the long run. I also relate my results to Clarida and Gali (1994), estimating their three-variable model on my data and my five-variable model on their data. This analysis suggests that the effect of multiple aggregation of shocks discussed by Faust and Leeper (1997) is empirically important.

Baseline Case: Model with $X=\{\Delta(G / Y), \Delta(y), \Delta(r), \Delta(\mathrm{mm}), \Delta(\mathrm{h})\}$

I first examine the case in which the vector of stationary variables $\mathrm{X}=\{\Delta(\mathrm{G} / \mathrm{Y}), \Delta(\mathrm{y}), \Delta(\mathrm{r})$, $\Delta(\mathrm{mm}), \Delta(\mathrm{h})\}$, with the vector of shocks $\epsilon=\left\{\epsilon^{\mathrm{g}}, \epsilon^{\mathrm{S}}, \epsilon^{\mathrm{D}}, \epsilon^{\mathrm{mm}}, \epsilon^{\mathrm{h}}\right\}$. The transformed variables are assumed to be related in the long run as given by the matrix $\mathrm{C}(1)$ :

$$
X=\left[\begin{array}{l}
\Delta(G / Y) \\
\Delta(y) \\
\Delta(r) \\
\Delta(m m) \\
\Delta(h)
\end{array}\right] \quad \varepsilon=\left[\begin{array}{l}
\varepsilon^{g} \\
\varepsilon^{s} \\
\varepsilon^{D} \\
\varepsilon^{m m} \\
\varepsilon^{h}
\end{array}\right] \quad C(1)=\left[\begin{array}{lllll}
c_{11} & 0 & 0 & 0 & 0 \\
c_{21} c_{22} & 0 & 0 & 0 \\
c_{31} c_{32} c_{33} & 0 & 0 \\
c_{41} c_{42} c_{43} c_{44} & 0 \\
c_{51} c_{52} c_{53} c_{54} & c_{55}
\end{array}\right]
$$

An intuitive justification for the lower triangularity of the model is as follows. First, the assumption that the long-run share of government spending in total output is exogenous implies the zerorestrictions in the top row. Second, assuming the classical dichotomy between real and monetary variables in the long run implies that, for rows 1,2, and 3 the elements in columns 4 and 5 are zero. Third, the assumption that the money multiplier is unaffected by the monetary base in the long run justifies the restriction $\mathrm{c}_{45}=0$. This does not imply that the money multiplier is constant, as it may change through $\epsilon^{\mathrm{mm}}$. The final zero-restriction, $\mathrm{c}_{23}=0$, implies that $\epsilon^{\mathrm{D}}$, which may be thought of as a "demand" or "preference" shock (for traded goods relative to non-traded goods as discussed below), has no effect on output in the long run.

To fix ideas on the interpretation of these permanent disturbances, I analyze the steady-state properties of an extended version Rogoff's (1992) model, in which I add preference shocks, in the form 
of a disturbance to traded goods consumption, and money, via a cash-in-advance constraint. The model is contained in the appendix. Here, I attempt to give an intuitive, verbal interpretation of the shocks.

Fiscal shocks, $\epsilon^{\mathrm{g}}$, are exogenous, permanent disturbances to the size of government $(\mathrm{G} / \mathrm{Y})$. An important example might be the creation of a system of social insurance programs. Notice from equation (3) that these disturbances are allowed to have a long-run effect on each variable in the VAR. Aggregate supply or productivity shocks, $\epsilon^{\mathrm{S}}$, include any disturbances that affect the long-run level of output beyond fiscal shocks, such as improvements in technology. These shocks, by construction, have no longrun effect on $(\mathrm{G} / \mathrm{Y})$, but are allowed to affect the real exchange rate, money multiplier, and monetary base.

Next consider the types of disturbances that might correspond to $\epsilon^{\mathrm{D}}$. By construction, these may have a long-run effect on the real exchange rate, but not government size or output. An important example would be changes in trade policy. Large realizations of $\epsilon^{\mathrm{D}}$ may have resulted from the disruption of trade during the war years in the sample. These shocks include any shifts in preferences ("involuntarily" or otherwise) towards or away from traded goods. The histories of both countries, especially the U.S., are filled with important changes in trade policy (Robertson (1973)).

There are several possible interpretations of money multiplier shocks, $\epsilon^{\mathrm{mm}}$ : (I) shocks to the currency-deposits ratio, (ii) changes in the reserves-deposits ratio brought about by new bank legislation or by changes in reserve requirements, or (iii) real aggregate demand changes that have no long-run effect on government size, output, or the real exchange rate, but get transmitted to broad money through the dependence of the money supply on interest rates. Exogenous disturbances to the real monetary base, $\epsilon^{\mathrm{h}}$, correspond most closely to monetary policy shocks. ${ }^{8}$

${ }^{8}$ There is a large debate in the literature about identifying monetary policy shocks [for a recent contribution that also provides an overview of the literature, see Faust (1998)]. This work, which focuses mostly on closed-economy issues, suggests that the monetary base shock I identify is not necessarily the most appropriate proxy for policy shocks. This criticism is less important here because my goal is to assess the relative contribution of monetary versus non-monetary shocks to the real exchange rate, as opposed to measuring, e.g., a liquidity effect on interest rates. 


\section{Estimates of the Baseline Model}

The "baseline" VAR model described by equations (1)-(3) is estimated using seven lags of X. This configuration is based on the test results in section 1. Because of the borderline nature of some of those results, alternative specifications are also examined. The rationale for each alternative specification is discussed as estimates of the model are presented. The sample period is 1889-1992.

Plots of the five structural disturbances are presented in figure 2. Lagrange multiplier tests for autocorrelation of up to eight lags indicate that each of the residual series is serially independent. I also report in figure 2 the standard deviation of the disturbance series. All but four of the residuals are within three standard deviations of the mean of zero: the fiscal shock in 1932, which is just over three times the standard error; the supply shock in 1940 (four times its standard error), the money multiplier shock in 1914 (three and one-half times its standard error), and the monetary base shock in 1980 (three and onehalf times its standard error). Approximately $90 \%$ are within twice the standard error. Although there are more "large" residuals relative to what would be found under the normal distribution, and although the outliers listed above occur on dates that are associated with important economic events, they do not seem to be so unusually large as to treat them as structural breaks. On the hand, the plots of the structural disturbances do not guarantee that the results will be time-invariant. In the final section of the paper, I show that my conclusions are robust when estimation is restricted to the post-Bretton Woods era.

Impulse responses of the level of each variable are displayed in figure 3. Solid lines are the point estimates, and dashed lines represent the $84^{\text {th }}$ and $16^{\text {th }}$ percentiles of the empirical distribution of the impulse responses from 1,000 Monte Carlo simulations of the model. (The interval would correspond to a one standard deviation confidence band under the normal distribution.) The plots suggest that my interpretation of the shocks is sensible. For example, output responds positively to positive fiscal and productivity shocks, as well as to positive monetary base shocks in the short run. Focusing on the real exchange rate, the demand shock, which is interpreted as a traded goods preference shock, leads to a persistent real depreciation. Fiscal and productivity shocks are insignificant at all horizons. The 
response of the real exchange rate to either the money multiplier or the monetary base shock is positive and significant in the short-run, but is not persistent. This pattern, a short-run real depreciation combined with a gradual return to the (unchanged) long-run level, suggests a type of overshooting behavior.

Variance decomposition (VDC) results constitute the main evidence of the paper. The VDCs for the baseline case are reported in table 4 . The robustness of these results is checked by estimating several alternative models, whose results are reported in table 5.

The upper panel of table 4 contains the VDCs of $\Delta(\mathrm{r} 1)$. The demand (preference) shock, the money multiplier shock, the monetary base shock, and -- to some extent -- the fiscal shock are all influential. As indicated by the final column, monetary shocks combined account for over 40 percent of the variance of real exchange rate changes. The effect is split into money multiplier shocks and monetary base shocks in roughly equal amounts. Preference shocks account for over 35 percent, while the fiscal shock accounts for over 10 percent. The supply (productivity) shock accounts for less than 6 percent at all horizons. The lower panel contains the VDCs of the level of $\mathrm{r} 1$. The contribution of the monetary shocks goes to zero in the long run, which is an identifying assumption. At shorter horizons, the relative contributions of the shocks are similar to that described for $\Delta(\mathrm{r} 1)$ : monetary shocks combined account for nearly one-half, with effects split approximately equally between base and multiplier shocks, while the remainder is mostly due to preference shocks.

To convey a sense of the uncertainty associated with these point estimates, table 4 also reports empirical percentiles of the distribution calculated from 1,000 Monte Carlo simulations of the baseline model. ${ }^{9}$ Although the confidence intervals are in general fairly wide, one can easily infer that monetary

${ }^{9}$ I report the $16^{\text {th }}$ and 84 th percentiles, which would correspond to a standard deviation confidence interval under the normal distribution. Other authors, including Clarida and Gali (1994) and Eichenbaum and Evans (1995), report the estimated standard error as opposed to empirical percentiles. The choice would be inconsequential if the variance components were distributed normally. However, the variance components must lie between zero and one, and do not appear to have a normal distribution. As noted above, the standard errors for the contribution of money shocks reported by other authors are fairly large: approximately two-thirds the magnitude of the point estimate in Eichenbaum-Evans and 5 to 7 times the point estimate in Clarida-Gali. 
shocks are important, or at least more important than reported elsewhere. For $\Delta(\mathrm{r} 1)$, estimates at the lower end of the confidence interval range from 16 percent at the one-year horizon to 29 percent at the twenty-year horizon. This compares to point estimates of around 17 percent in Eichenbaum and Evans and less than 3 percent in Clarida and Gali.

\section{Robustness: Estimating Alternative Models}

The basic result seems plausible, or at least non-extreme: real and monetary shocks account for roughly equal portions of the variance of the real exchange rate over short to intermediate horizons. And although such results may be unsurprising, they are different from what is in the literature. Of course, my results are obtained by applying to a long span of data a single structure -- a VAR model that is identified with restrictions such as long-run monetary neutrality and exogenous government size. These restrictions seem to be plausible when estimating a model for a long sample period encompassing different exchange rate regimes and degrees of capital mobility. However, since our judgement about what constitutes a plausible identifying restriction, and our tests used to specify the form of the model, are both far from infallible, it is worthwhile estimating alternative structures to assess robustness.

Table 5 presents the variance decomposition results from several alternative VAR models. For ease of comparison, the top row of the table reproduces the results above.

\section{Cases 1 and 2: Alternative Measures of the Real Exchange Rate}

In the first two alternatives, labeled cases 1 and $2, \mathrm{r} 1$ is replaced by $\mathrm{r} 2$ and $\mathrm{r} 3$-- the GDP deflator-based real exchange rate and proxy for the relative price of non-tradeables, respectively. The top two panels of Figure 1 display the three series. Although $\mathrm{r} 1$ and $\mathrm{r} 2$ are highly correlated $(0.81), \mathrm{r} 3$ behaves quite differently from the other two at times. This is because $r 3$ is conceptually very different: while the latter two measure the common-currency relative price of the same price index across countries, 
r3 is based on the ratio of two different price indexes within-country. Engel $(1993,1997)$ and Rogers and Jenkins (1995) discuss reasons why the latter construct may behave differently. ${ }^{10}$

For each of the two new systems, LR tests for lag length in the VAR and Johansen tests for cointegration indicate that a VAR in first-differences with 7 lags is appropriate, just as in the baseline model. These results are contained in the appendix.

Table 5 indicates that the VDC of $\mathrm{r} 2$ is very similar to that of $\mathrm{r} 1$. Monetary shocks combined account for $48.5 \%$ of the variance at the one-year horizon and $35 \%$ at the two-year horizon, although the contribution of $\epsilon^{\mathrm{h}}\left(\epsilon^{\mathrm{mm}}\right)$ is around 10 points lower (higher) in the model with $\mathrm{r}$. The VDC of $\mathrm{r}$, reported as case 2 of table 5, also indicates that the contribution of monetary shocks is around one-half in the short run. In this case, fiscal shocks account for very little of the short-term forecast error variance of the real exchange rate, in contrast to cases 0 and 1, where fiscal shocks accounted for around 12-20\%. In all three cases, supply shocks have virtually no effect.

\section{Case 3: Lag Length}

Case 3 assesses the robustness of the baseline model to changes in the VAR lag length of seven. Likelihood ratio tests for the system $\{\Delta(\mathrm{G} / \mathrm{Y}), \Delta \mathrm{y}, \Delta \mathrm{r} 1, \Delta \mathrm{mm}, \Delta \mathrm{h}\}$ reject at $10 \%$ the hypothesis that lags 7 are zero. This suggests that a 6-lag VAR can be rejected in favor of a 7-lag VAR at 10\%, and is consistent with 8 lagged levels appearing in the VAR as in table 2. However, tests with only slightly shorter lag lengths do only marginally worse: we can reject a 5-lag VAR in favor of a 6-lag VAR, and reject a 4-lag VAR in favor of a 5-lag VAR each at 13\%. None of the other tests produces a lower pvalue. In light of Faust and Leeper's point that results using the Blanchard-Quah scheme will be correct only if the estimated reduced-form VAR is the correct representation, these LR test results suggest also looking at lag lengths of 6 and 5.

\footnotetext{
${ }^{10}$ Note that the difference is not due noticeably different behavior of the three price indexes themselves. The correlation between the U.S.-U.K. relative GDP deflator and relative WPI is 0.97, and that between the U.S.-U.K. relative GDP deflator and relative government spending deflator is 0.92 .
} 
Table 5 reports the results for the VAR with 5 lags of $\{\Delta(\mathrm{G} / \mathrm{Y}), \Delta \mathrm{y}, \Delta \mathrm{r} 1, \Delta \mathrm{mm}$, and $\Delta \mathrm{h}\}$. As seen from the row labeled case 3, the VDCs are very close to those of the baseline model. Monetary shocks combined account for $41.4 \%$ of the variance at the one-year horizon and $36 \%$ at the two-year horizon. Once again, the contribution of supply shocks is essentially zero at short horizons. The results using 6 lags (not reported) are also not noticeably different from the baseline case: at the one-year horizon, monetary shocks combined contribute $31.1 \%$, while the contributions of $\epsilon^{\mathrm{g}}, \epsilon^{\mathrm{S}}$, and $\epsilon^{\mathrm{D}}$ are, respectively, $16.5 \%, 0.55 \%$, and $51.8 \%$. Therefore, changes in lag length in the vicinity of that used in the baseline case do not have large effects on the results.

\section{Cases 4, 5 and 6: Models with Trend-Stationary (G/Y) and r1}

Cases 4-8 of table 5 are motivated by the first Faust-Leeper criticism discussed above. Faust and Leeper (1997, section 2.2) offer two suggestions toward resolving the problem: test the system variables for unit roots using the null of trend-stationarity (in addition to the unit root null), and identify the VAR under restrictions other than long-run restrictions to see how well the long-run restrictions hold.

Section 1 above and table 1 discuss the results of the $\operatorname{KPSS}(\tau)$ test, which has trend-stationarity as its null, as well as the ADF test and the 95\% confidence intervals for the largest autoregressive root [Stock (1991)]. In light of the uncertainty highlighted by these test results, cases 4, 5 and 6 of table 5 examine models in which $(\mathrm{G} / \mathrm{Y})$ and $\mathrm{r} 1$ are stationary.

\section{Case 4: Trend-Stationary $r 1$}

Dropping the unit root specification for some of the series raises issues of econometric identification and economic interpretation. As long as the variables in $\mathrm{X}$ are stationary, recovering the structural MA representation (1) from the reduced-form VAR proceeds just the same when some variables appear in levels as when all variables enter in first-differences. It is true that switching from $\mathrm{I}(1)$ variables to $\mathrm{I}(0)$ variables has implications for the way in which variables enter the reduced-form VAR, equation (2), but not for the way in which (1) is recovered from (2). I demonstrate this in an appendix that is available on request. 
The economic issues that arise are more subtle. For example, two direct implications of the assumption that the real exchange rate is trend-stationary are that none of the shocks has a permanent effect on the level of $r$, and one-time shocks to the real exchange rate have only transitory effects. In addition, estimation with the real exchange rate in levels rather than first-differences alters the interpretation of the zero restrictions. For example, in equation (3), where $\mathrm{X}$ contains all first-differenced variables, the restriction $c_{35}=0$ is justified by the classical dichotomy between real and nominal variables: shocks to the monetary base have no effect on the level of the real exchange rate in the long run. If we were to replace $\Delta(\mathrm{r})$ with $\mathrm{r}^{\tau}$ (r, with a deterministic time trend removed) and keep the ordering in (3), the restriction $\mathrm{c}_{35}=0$ would no longer have a basis in economic theory, as it would state that money shocks have no effect on the accumulated level of the real exchange rate in the long run.

Thus, in the case of a stationary real exchange rate I order the variables as follows:

$$
X=\left[\begin{array}{c}
\Delta(G / Y) \\
\Delta(y) \\
\Delta(m m) \\
\Delta(h) \\
r^{\tau}
\end{array}\right] \quad \varepsilon=\left[\begin{array}{l}
\varepsilon^{g} \\
\varepsilon^{s} \\
\varepsilon^{m m} \\
\varepsilon^{h} \\
\varepsilon^{D}
\end{array}\right] \quad C(1)=\left[\begin{array}{lllll}
c_{11} & 0 & 0 & 0 & 0 \\
c_{21} c_{22} & 0 & 0 & 0 \\
c_{31} c_{32} c_{33} & 0 & 0 \\
c_{41} c_{42} c_{43} c_{44} & 0 \\
c_{51} c_{52} c_{53} c_{54} & c_{55}
\end{array}\right]
$$

Equations (4) reflect the following: (i) none of the shocks has a permanent effect on the level of the real exchange rate, and (ii) one-time changes in the orthogonalized component of the real exchange rate shock, $\epsilon^{\mathrm{D}}$, have no long-run effects on the level of any variable, while (iii) the rest of the zero restrictions are justified exactly as in the baseline case (exogenous long-run share of government spending in output, the classical dichotomy, and a long-run unit elasticity of the money supply with respect to the monetary base).

The variance decompositions are reported as case 4 in table 5. Although the contribution of monetary base shocks is nearly identical to that of case 0 , the contribution of money multiplier shocks at short and medium horizons is $20-25 \%$ less than in the baseline model. Thus, for the first time, the 
combined contribution of monetary shocks on impact is less than $40 \%$. Notably, in case 4 the contribution of the output supply shock is 15.8 and 25.2 at the 1-year and 2-year horizons, respectively, making it the first case in which its contribution is greater than 5\%. This increase in the contribution of supply shocks is mirrored by a decreased influence of fiscal shocks. ${ }^{11}$

\section{Case 5: Stationary $(G / Y)$}

Case 5 of table 5 reports the VDCs for the model with $(\mathrm{G} / \mathrm{Y})$ assumed to be stationary. Following the line of reasoning in case 4 above, we place the stationary variable last in the ordering. Thus, $\mathrm{X}=$ $\{\Delta(\mathrm{y}), \Delta(\mathrm{r} 1), \Delta(\mathrm{mm}), \Delta(\mathrm{h}),(\mathrm{G} / \mathrm{Y})\}$, and $\epsilon^{\mathrm{g}}$ is by construction a transitory disturbance. The VDCs indicate a decline of 5-10\% in the contribution of each of the monetary shocks compared to the baseline case. This decline is made up by an almost equivalent rise in the contribution of the aggregate demand shock. Fiscal shocks are approximately equally influential in this case as compared to case 0 , implying that once again the contribution of aggregate supply shocks is essentially nil.

\section{Case 6: Trend-Stationary $r 1$ and Stationary $(G / Y)$}

In this case, the unit root assumption is dropped for both $(\mathrm{G} / \mathrm{Y})$ and $\mathrm{r} 1$. The ordering of variables is now $\left\{\Delta(\mathrm{y}), \Delta(\mathrm{mm}), \Delta(\mathrm{h}),(\mathrm{G} / \mathrm{Y}), \mathrm{r} 1^{\tau}\right\}$. The contribution of each of the three permanent shocks -- $\epsilon^{\mathrm{S}}$, $\epsilon^{\mathrm{mm}}$, and $\epsilon^{\mathrm{h}}-$ - is very close to that of case 4 , in which only $\mathrm{r} 1$ is treated as stationary. ${ }^{12}$

Cases 4 through 6 indicate that consideration of the univariate time-series properties of the individual variables is potentially important for the results of structural VAR estimation. Prior to case 4,

\footnotetext{
${ }^{11}$ When I estimate the system with a trend-stationary $\mathrm{r}$, while keeping the ordering of variables the same as the baseline case, the combined effect of monetary shocks is larger than in any of the 9 cases reported in table 5: $60.2 \%$ at the 1-year horizon and 56\% at the 2-year horizon. The additional contribution of monetary shocks comes entirely at the expense of the own shock, as the contributions of the fiscal and supply shocks are unaffected by the re-ordering.

${ }^{12}$ Note that $\epsilon^{\mathrm{g}}$ and $\epsilon^{\mathrm{D}}$ are both transitory disturbances which are now not identified separately from one another. The combined contribution of $\epsilon^{\mathrm{g}}$ and $\epsilon^{\mathrm{D}}$ is $62.4,63.0$, and 27.9, at horizons 1, 2, and 20 , respectively. Also, note that when I estimate this system with the ordering of the baseline case, the contribution of monetary shocks is $28.3 \%$ at 1 -year and $33.1 \%$ at 2 years.
} 
we had solid evidence that: (a) that the influence of (combined) real shocks and monetary shocks is approximately equal, and (b) that the contribution of aggregate supply shocks is essentially zero. Case 4 shows, however, that these two inferences are somewhat sensitive to treating the real exchange rate as trend-stationary instead of difference-stationary. At the same time, cases 5 and 6 indicate that the choice is less crucial in the case of the fiscal variable.

\section{Cases 7-9: Rethinking the Long-Run Assumptions}

The long-run restriction that "demand" or "preference" shocks, $\varepsilon^{\mathrm{D}}$, have no long-run effects on output may be the most difficult to justify a priori. ${ }^{13}$ In case 7 I reverse the ordering of $\Delta \mathrm{y}$ and $\Delta \mathrm{r} 1$ from the baseline system. As seen in table 5, there is a slight increase (decrease) in the contribution of $\epsilon^{\mathrm{S}}\left(\epsilon^{\mathrm{D}}\right)$ of $2-4 \%$, while the contributions of $\varepsilon^{\mathrm{g}}, \varepsilon^{\mathrm{mm}}$, and $\varepsilon^{\mathrm{h}}$ are essentially the same as in the baseline case.

As noted above, Faust and Leeper urge practitioners of the long-run identification scheme to identify the VAR under other restrictions and see how close the long-run restrictions come to holding. Figure 4 depicts the impulse responses of the system $\mathrm{X}=\{\Delta(\mathrm{G} / \mathrm{Y}), \Delta(\mathrm{y}), \Delta(\mathrm{r} 1), \Delta(\mathrm{mm}), \Delta(\mathrm{h})\}$ from a VAR identified using zero restrictions on the contemporaneous correlations of innovations, as in Sims (1980); all long-run responses are unrestricted. A plus- and minus- two standard error confidence band around each impulse response is also plotted.

I use these impulse responses as a guide to several re-orderings of the variables in the long-run model. This ad hoc approach to dealing with the problem is not foolproof, but is in the spirit of Faust and Leeper's recommendations. It is recognized that such re-orderings alter the interpretation of the shocks in the baseline model, as did the treatment of $\mathrm{r} 1$ as trend-stationary in case 4 .

The middle column of figure 4 depicts the response of $r 1$ to each of the 5 shocks. From the final two rows, it is seen that $\mathrm{r} 1$ goes to zero after about 5 years in response to a monetary base shock, but does

\footnotetext{
${ }^{13}$ Barro and Sala-I-Martin (1995) find that output growth is positively affected by terms-of-trade growth in a cross-section of countries.
} 
not go to zero in response to a money multiplier shock. Thus if one believes in the restrictions used to identify the model that generates these impulse responses, figure 4 suggests that the long-run restriction $\mathrm{c}_{34}=0$ in equation (3) may be suspect.

In case 8, I relax the long-run restriction $\mathrm{c}_{34}=0$ by placing $\Delta(\mathrm{mm})$ ahead of $\Delta(\mathrm{r} 1)$ in the system, and re-estimate the model with the long-run restrictions implied by the new ordering. As seen in table 5, output supply shocks and combined monetary shocks each contribute approximately $18 \%$ to the forecast error variance of $\mathrm{r} 1$ at the one-year horizon. The remainder is accounted for by the aggregate demand shock. Interestingly, the contribution of the money multiplier shock goes to zero in the long run, just as in the baseline case, even though it is no longer restricted to do so.

Figure 4 also indicates that the response of the money multiplier to $\epsilon^{\mathrm{h}}$ is also non-zero in the long-run. When I re-estimate the long-run model switching the order of $\Delta(\mathrm{mm})$ and $\Delta(\mathrm{h})$, the results are very similar to the baseline case (and so are not reported in table 5): the difference in the contributions of fiscal, supply, and demand shocks is less than one-half of one percent at every horizon. Furthermore, in the model with the new ordering, monetary base shocks contribute $(8.27 \%, 17.5 \%, 20.7 \%)$ at the 1,2 , and 5-year horizons, respectively, while the contribution of money multiplier shocks over the same horizons is $(32.3 \%, 21.7 \%$, and $11.5 \%)$. Thus, only the relative contributions of the two disaggregated monetary shocks is affected by this re-ordering.

Finally, the impulse responses in figure 4 indicate that, when identified using short-run restrictions, shocks to aggregate supply and to the monetary base have significant long-run effects on (G/Y). To address these two possible sources of mis-specification in the baseline long-run model, I first re-estimate that model reversing the ordering of $\Delta(\mathrm{G} / \mathrm{Y})$ and $\Delta \mathrm{y}$. The results, which are not reported, are nearly identical to the baseline case. Next, I re-estimate the long-run model with $\Delta(\mathrm{G} / \mathrm{Y})$ ordered last, i.e., with $\mathrm{X}=\{\Delta(\mathrm{y}), \Delta(\mathrm{r} 1), \Delta(\mathrm{mm}), \Delta(\mathrm{h}), \Delta(\mathrm{G} / \mathrm{Y})\}$. Results are reported as case 9 in table 5. Although monetary shocks combined account for $35-50 \%$ of the forecast error variance of $\mathrm{r} 1$ at short horizons, this is almost entirely due to $\epsilon^{\mathrm{mm}}$. The other notable difference between this and the baseline case is in the 
contribution of the aggregate supply shock: $10-20 \%$ at short horizons, with a steady state of $22 \%$. An implication of this particular ordering is that shocks to each of the system variables has a permanent effect on the level of $(\mathrm{G} / \mathrm{Y})$, which is at odds with $(\mathrm{G} / \mathrm{Y})$ being stationary.

Summary

The benefit of examining several alternative cases, even if it is believed that one specification is most plausible a priori, is that we obtain a "boundary"of sorts on the influence of the shocks. For example, the 12 cases reported here suggest a "lower- and upper-bound estimate" of the contribution of monetary shocks on impact equal to $18.7-60.2 \%$, with a mean contribution of $37.1 \%$ and median contribution of $40.6 \%$. This lower bound estimate is thus slightly larger than the mean contribution of monetary shocks reported by Eichenbaum and Evans (1995) for the U.K., and is considerably larger than the estimated contribution of monetary shocks for the U.K. found by Clarida and Gali (1994).

Table 5 also provides a lower- and upper-bound estimate of the contribution of $\epsilon^{\mathrm{D}}$ equal to $35.9 \%-63.2 \%$ with a mean of $48.6 \%$. Because this is the effect of the "own shock" to the real exchange rate, one rough interpretation is that, in our typical VAR, one-half of the error variance of the real exchange rate is explained by the fundamentals identified with the other system shocks (and one-half is not!). Finally, table 5 informs us as to the influence of two "real shocks", $\epsilon^{\mathrm{g}}$ and $\epsilon^{\mathrm{s}}$. Their combined effect in the short run is at most $25.6 \%$ (the two-year horizon in case 4), and their mean contribution is $14.5 \%$ at the one-year horizon and $17.3 \%$ at the two-year horizon.

The alternative cases also provide insights into those aspects of the baseline configuration which, when changed, lead to differences in the relative contributions of the shocks. Recall that the short-run contributions in the baseline model are roughly: preference (or "own") shocks (40-50\%), monetary shocks (35-45\%), fiscal shocks (10-15\%), and supply shocks (zero). Two alterations of the baseline configuration have noticeable effect on the results: (i) treating the real exchange rate as trend-stationary; and (ii) relaxing the assumption of long-run neutrality of the real exchange rate with respect to a monetary shock. Each has the effect of lowering the short-run contribution of fiscal and monetary shocks 
and raising the short-run contribution of demand ("own") shocks and supply shocks. In each case, the magnitude of the change in contribution is roughly $10-15 \%$.

The robustness analysis characterizes how much different from the baseline model an alternative model must be in order to get noticeably different results. For example, the models of cases 4 and 8 are derived from distinctly different building blocks: in case 4, the real exchange rate is treated as trendstationary, implying that none of the system shocks has a permanent effect on the level of r1; in case 8, $\Delta(\mathrm{r} 1)$ is moved down in the ordering, implying that even more of the system shocks can have a permanent effect on the level of r1 compared to the baseline case. Both models indicate that nearly twothirds of the VDCs of the real exchange rate is due to own shocks, with supply shocks and monetary shocks accounting for equal amounts, about $15-20 \%$ each.

\section{An Encompassing-Style Analysis of Clarida and Gali (1994)}

Clarida and Gali (1994) use a similar methodology to examine sources of movements in real exchange rates among the United States, Canada, Germany, Japan, and the United Kingdom for the postBretton Woods era. Their VAR system contains $(\Delta \mathrm{y}, \Delta \mathrm{r}$, and $\pi)$, where y is the U.S.-foreign country differential in GDP growth, $\mathrm{r}$ is the real CPI exchange rate, and $\pi$ is the (CPI) inflation differential. The corresponding shocks are labeled aggregate supply, aggregate demand, and nominal (or monetary)

shocks. The identifying assumptions include that, in the long run, permanent disturbances to the ratio of the domestic-foreign price level have no effect on the real exchange rate or the output differential, and that permanent disturbances to the real exchange rate have no effect on the output differential. Thus, their ordering of $\Delta y$ and $\Delta r$, and their assumption that $\mathrm{r}$ is I(1), are the same as in my baseline case.

I examine Clarida and Gali's results, and re-evaluate my own, in tables 6 and 7. Table 6 presents selected tests for lag length and cointegration. These are used to guide specifying the VARs that follow.

Table 7 displays the variance decompositions of the real exchange rate. In table 7A, the row labeled (CG) displays, by country, results taken from table 4 of Clarida and Gali (1994). The next row, 
labeled case (1), represents my replication of their results. ${ }^{14}$ For both the U.K. and Canada, monetary shocks are unimportant at all horizons, as aggregate demand shocks account for almost all of the variance of the real exchange rate. Monetary shocks are noticeably more important for Germany and Japan. In cases (2) and (3), respectively, I examine the robustness of these results to estimating the VAR with an alternative lag length based upon the LR tests of table 6A and to using GDP deflators instead of CPIs to calculate $\mathrm{r}$ and $\pi$. As seen in table 7A, the results are robust to either extension for all countries.

In explaining their results for the U.K. and Canada, Clarida and Gali (p.51) speculate that nominal shocks would turn out to be more important in either a different, or a larger, information set. In the remainder of table 7, I investigate this by estimating their three-variable model on my long-term data set (table 7B), and by estimating my five-variable model on U.K. and Canadian data from the ClaridaGali sample period (table 7C).

Part B of table 7 displays estimates of Clarida and Gali's model on my long-term U.S.-U.K. data set. I report results for two different definitions of the real exchange rate, one using wholesale prices (labeled r1) and the other using GDP deflators (r2) (recall that the CPI is unavailable over this long horizon). I also consider two alternative lag lengths, 4 and the lag length chosen by a LR test. According to table $7 \mathrm{~B}$, the permanent disturbance to the real exchange rate (the "aggregate demand shock") is the dominant influence. In the short run, the monetary shock accounts for between 4 to 19 percent of the forecast error variance, an amount that is closer to what is reported for the post Bretton Woods era in part A of table 7 (0-5\%) than what I find in the baseline case of my five-by-five model using the long-term data (around 40-45\%). The average contribution of monetary shocks across the four

\footnotetext{
${ }^{14}$ Results are displayed for $\Delta(\mathrm{r})$ only. Clarida and Gali obtain their price data from International Financial Statistics (IFS), the output data from the OECD Main Economic Indicators, and the exchange rate from the New York Fed's database. I use the same sources for prices and output, and take the exchange rate from IFS. Revisions to the data may account for the small differences in results. Note from table $6 \mathrm{~B}$ that there is fairly strong evidence of one cointegration vector in the Canadian threevariable systems, but not for that of the U.K. (or for Germany and Japan, whose results are not displayed). Clarida and Gali (footnote 5) note that they also find one cointegration vector for Canada, but nonetheless estimate a VAR in first differences. Because my aim is to replicate Clarida and Gali's findings, I also estimate a VAR in first differences without imposing any cointegrating relationships.
} 
specifications is $13.2 \%$ at one year and $17.8 \%$ at five years. Notice that monetary shocks are more important in the systems containing the GDP deflator-based real exchange rate, $r 2$, than in those with $\mathrm{r} 1$, which is based on wholesale price indices. This is perhaps because the proportion of non-tradables in GDP deflators is larger than that in WPIs.

Finally, in part $\mathrm{C}$ of table 7 I estimate my baseline five-by-five model on the Clarida-Gali sample. I focus on Canada and the U.K., the two cases in which Clarida and Gali find no role for monetary shocks. I use the same data for prices, output and exchange rates that was used to replicate the authors results in table 7A. These series are supplemented with data on money supply, monetary base, and real government spending. The data used in both the U.K. and Canadian VARs are displayed in figure 5 over the Clarida-Gali sample period 1974-1992. The plots reveal a broad similarity between movements in each U.K.-U.S. variable and its Canada-U.S. counterpart. ${ }^{15}$ Tests for VAR lag length and cointegration displayed in table 6 are used to determine the model specifications. There is virtually no evidence of cointegration in the 5-variable VARs. The sole exception is a borderline rejection of zero cointegration vectors for the U.K. system with 6 lags, where the trace test statistic of 68.8 is slightly larger than the 5\% critical value of 68.5. However, note that in the same case, Johansen's (1991) maximum eigenvalue test fails to reject the null of zero cointegration vectors at $5 \%$, as do tests with alternative lag lengths of 5 (not shown in table 6) and 8.

The results for the U.K. are displayed in the first four rows of table 7C. These four cases examine alternative VAR lag lengths and price deflators, as in table 7B. According to the table, monetary shocks are very important. Averaging across the four cases, the combined contribution of $\epsilon^{\mathrm{mm}}$ and $\epsilon^{\mathrm{h}}$ to the VDC of $\Delta(\mathrm{r})$ is $34.5 \%$ at the 1 -quarter horizon and $35.9 \%$ at the 20 -quarter horizon. Most

\footnotetext{
${ }^{15}$ The money supply and monetary base data are obtained from the respective central banks, via the database of the Bank for International Settlements. The source for the government spending data is the same as that for output -- the OECDs Main Economic Indicators. There are two exceptions to the broad similarity in the U.K. and Canadian plots: the output differential over the half of the sample, when Canadian (U.K.) growth typically exceeded (fell short of) U.S. growth, and the real exchange rate during the well-known period of sterling appreciation in the late 1970's.
} 
of the effect is due to shocks to the money multiplier. Fiscal shocks account for $12-16 \%$ of the variance of $\Delta(\mathrm{r} 1)$, the CPI-based real exchange rate, but are unimportant when GDP deflators are used $(\Delta \mathrm{r} 2)$. Table 7C also indicates that, for Canada, estimating the expanded model has only a minor effect on the contribution of monetary shocks. Instead, fiscal shocks are very important, accounting for nearly onehalf of the variance of the real exchange rate. This result is somewhat puzzling in light of the plots of the data, which do not reveal any large discrepancies in the U.K.-U.S. and Canada-U.S. series for government size, and warrants additional examination elsewhere.

Table 7 allows us to examine the source of the differences between my U.K. results and those of Clarida and Gali. Comparing table 7A (Clarida-Gali model on Clarida-Gali sample) to 7B (Clarida-Gali model on my long-term sample) suggests that the effect of using the longer data is to increase the contribution of the monetary shock, mostly at the expense of the aggregate demand shock, by about 10 to 20 percent. At the 1-year horizon, for example, the average contribution of monetary shocks across the four cases is $4.1 \%$ in table $7 \mathrm{~A}$ and $13.2 \%$ in table $7 \mathrm{~B}$. The contribution of the supply shock does not increase noticeably. Now compare table 7A (Clarida-Gali model, Clarida-Gali sample) to table 7C (my model, Clarida-Gali sample). The expanded model (i) allows certain AD disturbances -- permanent disturbances to government size -- to affect output in the long run, and (ii) contains a decomposition of the monetary disturbance. The effect of estimating the expanded model is to increase the contribution of monetary shocks from nearly zero to $50 \%$ or more in some cases, with an average contribution of $36.1 \%$ at the 1-year horizon. Hence, at least for Clarida and Gali's estimates for the U.K., the effect of multiple aggregation of shocks discussed by Faust and Leeper (1997) is very important. Finally, a comparison of table 7C (my model, Clarida-Gali sample) and table 5 (my model, my sample) indicates that the choice of model is more important than the choice of sample period for making inferences about the sources of real exchange rate movements.

\section{Conclusions}


An early strand of the literature often concluded that the high correlation between nominal and real exchange rates and the non-neutrality of real exchange rate variability across exchange rate regimes were evidence in support of models that emphasize monetary shocks and sticky prices [e.g., Dornbusch (1976)]. Recently, an influential literature that includes Obstfeld and Rogoff (1995), Beaudry and Devereux (1995), Chari, Kehoe, and McGrattan (1996), and Atkeson and Kehoe (1997) has examined whether certain stylized facts associated with real exchange rate movements can be replicated in dynamic general equilibrium models. These papers focus exclusively on the effects of monetary shocks.

Ironically, in light of this focus, papers that have attempted to directly identify various shocks to the real exchange rate and compare their relative magnitudes often find that monetary shocks are unimportant [Clarida and Gali (1994), Eichenbaum and Evans (1995)]. Perhaps this suggests that more emphasis be placed on shocks to technology, tastes, and trade and fiscal policies, since these can also be reconciled with the stylized facts on real exchange rates [Stockman (1988)].

The evidence presented in this paper indicates that, on the contrary, monetary shocks are generally very important for real exchange rate movements. Employing a structural VAR analysis on a long-term data set for the U.S. and U.K., I find that monetary shocks typically account for nearly one-half of the forecast error variance of the real exchange rate over short horizons. Evidence from several alternative models reveals a minimum contribution of monetary shocks equal to nearly $20 \%$. This suggests that the focus on monetary shocks in the recent dynamic general equilibrium literature is wellfounded empirically as well as theoretically. The estimates are also informative concerning the nature of these shocks: the real shocks are due more to fiscal and trade polices than technology changes (which, for the U.K. relative to the U.S., perhaps were not very large over much of the sample), while the money multiplier and monetary base shocks are roughly equally influential.

My paper is also the first in this branch of the literature to take seriously the Faust-Leeper (1997) critique of structural VARs, by examining the robustness of my baseline conclusions to several alternative specifications. My finding that the aggregation of multiple shocks implicit in Clarida and 
Gali's three-variable model (compared to my five-variable model) can have a non-trivial effect on the contribution of nominal shocks is evidence of the importance of their critique. These robustness checks demonstrate how different model configurations may give rise to different results, and take my VAR analysis a step in the direction advocated recently by Faust (1998).

\section{REFERENCES}

Ahmed, S., Ickes, B., Wang, P., and Yoo, S., 1993. International Business Cycles. American Economic Review 83, 335-359.

Atkeson, A., and Kehoe, P., 1997. Exchange Rates in Segmented Markets. Department of Economics, University of Minnesota.

Barro, R., and Sala-I-Martin, X., 1995. Economic Growth. (McGraw-Hill, New York).

Baxter, M., 1994. Real Exchange Rates and Real Interest Rate Differentials: Have We Missed the Business-Cycle Relationship? Journal of Monetary Economics 33, 5-37.

Beaudry, P., and Devereux, M., 1995. Money and the Real Exchange Rate with Sticky Prices and Increasing Returns. Carnegie-Rochester Conference Series on Public Policy 43, 55-102.

Blanchard, O., and Quah, D., 1989. The Dynamic Effects of Aggregate Demand and Supply Disturbances. American Economic Review 79, 655-72.

1993. The Dynamic Effects of Aggregate Demand and Supply

Disturbances: Reply. American Economic Review 83, 653-58.

Blough, S., 1992. The Relationship Between Power and Level for Generic Unit Roots Tests in Finite Samples. Journal of Applied Econometrics 7, 295-308.

Campbell, J., and Clarida, R., 1987. The Dollar and Real Interest Rates: An Empirical Investigation. Carnegie-Rochester Conference Series on Public Policy 27, 103-140.

Clarida, R., and Gali, J., 1994. Sources of Real Exchange Rate Fluctuations: How Important are Nominal Shocks? Carnegie-Rochester Conference Series on Public Policy 41, 1-56.

Chari, V., Kehoe, P., and McGrattan, E., 1996. Monetary Shocks and Real Exchange Rates in Sticky Price Models of International Business Cycles. University of Minnesota

Diebold, F., Husted, S., and Rush, M., 1991. Real Exchange Rates Under the Gold Standard. Journal of Political Economy 99, 1252-1271.

Dornbusch, R., 1976. Expectations and Exchange Rate Dynamics. Journal of Political Economy 84, 1161-1176. 
Edison, H., 1987. Purchasing Power Parity in the Long Run: A Test of the Dollar/Pound Exchange Rate (1890-1978). Journal of Money, Credit, and Banking 19, 376-387.

Edison, H., and Pauls, D., 1993. A Re-Assessment of the Relationship Between Real Exchange Rates and Real Interest Rate: 1974-1990. Journal of Monetary Economics 31, 149-164.

Eichenbaum, M., and Evans, C., 1995. Some Empirical Evidence on the Effects of Monetary Policy Shocks on Exchange Rates. Quarterly Journal of Economics 110, 975-1010.

Enders, W., and Lee, B., 1997. Accounting for Real and Nominal Exchange Rate Movements in the Post-Bretton Woods Period. Journal of International Money and Finance 16, 233-254.

Engel, C., 1993. Is Real Exchange Rate Variability Caused by Relative Price Changes? An Empirical Investigation. Journal of Monetary Economics 32, 35-50.

Engel, C., 1996. Long-Run PPP May Not Hold After All. University of Washington.

Engel, C., and Rogers, J., 1996. How Wide is the Border? American Economic Review 86, 1112-1125.

Faust, J. and Leeper, E., 1997. When Do Long-run Identifying Restrictions Give Reliable Results? Journal of Business and Economic Statistics 15, 345-353.

Faust, J., 1995. Near Observational Equivalence and Unit Root Processes: Formal Concepts and Implications. Econometric Theory 12, 724-731.

Faust, J., 1998. The Robustness of Identified VAR Conclusions About Money. Board of Governors of the Federal Reserve System, International Finance Discussion Paper \#610, Washington, DC.

Frankel, J., 1986. International Capital Mobility and Crowding-Out in the U.S. Economy: Imperfect Integration of Financial Markets or Goods Markets? in R.W. Hafer, ed., How Open is the U.S. Economy? (Lexington Books).

Friedman, M., and Schwartz, A., 1982. Monetary Trends in the United States and the United Kingdom. National Bureau of Economic Research.

Froot, K., and Rogoff, K., 1995. Perspectives on PPP and Long-Run Real Exchange Rates, in: G. Grossman and K. Rogoff, eds., Handbook of International Economics, Vol. 3 (North-Holland, Amsterdam) 1647-1688.

Johansen, S., 1991. Estimation and Hypothesis Testing of Cointegration Vectors in Gaussian Vector Autoregressive Models. Econometrica 159, 1551-80.

Kendrick, J., 1961. Productivity Trends in the United States. General Series, no.71. Princeton, NJ: Princeton University Press (for NBER).

Kwiatkowski, D., Phillips, P., Schmidt, P., and Shen, Y., 1992. Testing the Null Hypothesis of Stationarity Against the Alternative of a Unit Root. Journal of Econometrics 54, 159-178.

Lastrapes, W., 1992. Sources of Fluctuations in Real and Nominal Exchange Rates. Review of Economics and Statistics 74, 530-539. 
Lippi, M. and Reichlin, L., 1993. The Dynamic Effects of Aggregate Demand and Supply Disturbances: Comment. American Economic Review 83, 644-52.

Mark, N., 1990. Real and Nominal Exchange Rates in the Long Run: An Empirical Investigation. Journal of International Economics 28, 115-136.

Mark, N. 1997. An Empirical Investigation Into the Long-Run Determinants of the Pound-Dollar Exchange Rate. Ohio State University.

Meese, R., and Rogoff, K., 1988. Was it Real? The Exchange Rate-Interest Rate Differential Relationship Over the Modern Floating Rate Period. Journal of Finance 43, 933-948.

Mitchell, B., 1988. British Historical Statistics (Cambridge University Press, Cambridge).

Mussa, M. 1986. Nominal Exchange Rate Regimes and the Behavior of Real Exchange Rates: Evidence and Implications, in: K. Brunner and A. Meltzer, eds., Carnegie Rochester Conference Series on Public Policy 25, 117-214.

O'Connell, P., 1998. Overvaluation of Purchasing Power Parity. Journal of International Economics 44, $1-20$.

Obstfeld, M., and Rogoff, K., 1995. Exchange Rate Dynamics Redux. Journal of Political Economy 103, 624-660.

Osterwald-Lenum, M., 1992. A Note with Quantiles of the Asymptotic Distribution of the Maximum Likelihood Cointegration Rank Test Statistics. Oxford Bulletin of Economics and Statistics 54, 461-471.

Robertson, R.., 1973. History of the American Economy (Harcourt, Brace, and Jovanovich, New York).

Rogers, J., 1995. Real Shocks and Real Exchange Rates in Really Long-Term Data. International Finance Discussion Paper \#493, Federal Reserve Board.

Rogers, J., and Jenkins, M., 1995. Haircuts or Hysteresis? Sources of Movements in Real Exchange Rates. Journal of International Economics 38, 339-360.

Rogoff, K., 1992. Traded Goods Consumption Smoothing and the Random Walk Behavior of the Real Exchange Rate. NBER Working Paper 4119.

Sims, C., 1980. Macroeconomics and Reality. Econometrica 48, 1-48.

Stock, J., 1991. Confidence Intervals for the Largest Autoregressive Root in U.S. Macroeconomic Time Series. Journal of Monetary Economics 28, 435-459.

Stockman, A., 1983. Real Exchange Rates Under Alternative Exchange Rate Regimes. Journal of International Money and Finance 2, 147-166.

Stockman, A., 1988. Real Exchange Rate Variability Under Pegged and Floating Nominal Exchange Rate Systems: An Equilibrium Theory, in: K. Brunner and A. Meltzer, eds., Carnegie Rochester Conference Series on Public Policy 29, 259-294. 
Table 1: Tests for Unit Roots

\begin{tabular}{|c|c|c|c|c|c|c|c|}
\hline $\begin{array}{l}\text { Series / } \\
\text { Test : }\end{array}$ & $(\mathrm{G} / \mathrm{Y})$ & $\mathrm{y}$ & $\mathrm{r} 1$ & $\mathrm{r} 2$ & r3 & $\mathrm{mm}$ & $\mathrm{h}$ \\
\hline $\operatorname{ADF}(\tau)^{\mathrm{AIC}}$ & $\begin{array}{c}-3.74^{*} \\
(.962,1.000)\end{array}$ & $\begin{array}{c}-1.95 \\
(.988,1.046)\end{array}$ & $\begin{array}{c}-2.21 \\
(.985,1.044)\end{array}$ & $\begin{array}{c}-2.92 \\
(.975,1.036)\end{array}$ & $\begin{array}{c}-0.07 \\
(1.002,1.056)\end{array}$ & $\begin{array}{c}-2.33 \\
(.984,1.043)\end{array}$ & $\begin{array}{c}-2.77 \\
(.977,1.036)\end{array}$ \\
\hline $\operatorname{ADF}(\tau)^{5}$ & $\begin{array}{c}-3.52^{*} \\
(.966,1.002)\end{array}$ & $\begin{array}{c}-2.17 \\
(.985,1.044)\end{array}$ & $\begin{array}{c}-1.81 \\
(.990,1.047)\end{array}$ & $\begin{array}{c}-1.73 \\
(.990,1.048)\end{array}$ & $\begin{array}{c}-1.61 \\
(.992,1.049)\end{array}$ & $\begin{array}{c}-2.57 \\
(.979,1.039)\end{array}$ & $\begin{array}{c}-2.56 \\
(.979,1.039)\end{array}$ \\
\hline $\operatorname{KPSS}(\tau)^{\mathrm{AIC}}$ & $0.14^{\#}$ & $0.33^{* *}$ & $0.22^{* *}$ & $0.29^{* *}$ & $0.30^{* *}$ & $0.17^{*}$ & 0.06 \\
\hline $\operatorname{KPSS}(\tau)^{5}$ & 0.10 & $0.29^{* *}$ & $0.16^{*}$ & $0.13^{\#}$ & $0.41^{\text {** }}$ & $0.12^{\#}$ & 0.10 \\
\hline
\end{tabular}

Notes: ADF denotes the Augmented Dickey-Fuller test statistic for the unit root null hypothesis versus the trend-stationary alternative. In parenthesis are $95 \%$ confidence intervals for the largest autoregressive root in the series, calculated using the procedure of Stock (1991). KPSS denotes the Kwiatkowski, Phillips, Schmidt, and Shen (1991) test of the null of trend-stationarity. The sample period is 1889-1992. A \#, *, and ** indicates rejection of the null at $10 \%, 5 \%$, and $1 \%$, respectively. Lag length was either based on the Akaike Criterion or chosen arbitrarily to be 5 .

Table 2: Likelihood-Ratio Tests for Lag Length in the VAR

\begin{tabular}{lccccccccc}
$\begin{array}{l}\text { Lags / } \\
\text { LR-stat : }\end{array}$ & 9 vs. 8 & 8 vs. 7 & 7 vs. 6 & 6 vs. 5 & 5 vs. 4 & 4 vs. 3 & 3 vs. 2 & 2 vs. 1 & 8 vs. 5 \\
\hline \hline $\begin{array}{l}\text { LR } \\
\text { (p-value) }\end{array}$ & $\begin{array}{c}26.7 \\
(0.37)\end{array}$ & $\begin{array}{c}39.4 \\
(0.03)\end{array}$ & $\begin{array}{c}23.5 \\
(0.55)\end{array}$ & $\begin{array}{c}23.7 \\
(0.54)\end{array}$ & $\begin{array}{c}37.2 \\
(0.06)\end{array}$ & $\begin{array}{c}31.2 \\
(0.18)\end{array}$ & $\begin{array}{c}23.8 \\
(0.53)\end{array}$ & $\begin{array}{c}57.5 \\
(0.00)\end{array}$ & $\begin{array}{c}80.3 \\
(0.32)\end{array}$
\end{tabular}

Notes: LR denotes the likelihood ratio statistic used to test the null hypothesis that the $\mathrm{j}+1$ lags in each VAR equation are zero. The marginal significance level of the LR statistic is in parenthesis. The system variables are: $(\mathrm{G} / \mathrm{Y}), \mathrm{y}, \mathrm{rl}, \mathrm{mm}$, and $\mathrm{h}$. The sample period is 1889-1992.

Table 3: Tests of Cointegrating rank

\begin{tabular}{|c|c|c|c|c|c|c|c|c|}
\hline $\begin{array}{l}\mathrm{H}_{0}: \mathrm{CI} \\
\text { rank=p }\end{array}$ & $\begin{array}{r}\lambda \\
8 \text { lags } \\
\end{array}$ & $\begin{array}{r}\max . \mathrm{s} \\
5 \text { lags } \\
\end{array}$ & $\begin{array}{l}\text { at. } \\
2 \text { lags }\end{array}$ & $\begin{array}{c}95 \% \text { critical } \\
\text { value }\end{array}$ & $\begin{array}{r}\mathrm{T} \\
8 \text { lags } \\
\end{array}$ & $\begin{array}{l}\text { race st } \\
5 \text { lags }\end{array}$ & t. & $\begin{array}{c}95 \% \text { critical } \\
\text { value }\end{array}$ \\
\hline $\mathrm{p}=0$ & 24.7 & 26.5 & 29.4 & 33.5 & 47.9 & 49.1 & 50.5 & 68.5 \\
\hline $\mathrm{p} \leq 1$ & 9.17 & 10.8 & 10.5 & 27.1 & 23.2 & 22.6 & 21.2 & 47.2 \\
\hline $\mathrm{p} \leq 2$ & 8.93 & 8.24 & 6.74 & 21.0 & 14.0 & 11.8 & 10.7 & 29.7 \\
\hline $\mathrm{p} \leq 3$ & 5.10 & 3.57 & 3.85 & 14.1 & 5.11 & 3.58 & 3.94 & 15.4 \\
\hline$p \leq 4$ & 0.008 & 0.011 & 0.090 & 3.8 & 0.008 & 0.011 & 0.090 & 3.8 \\
\hline
\end{tabular}

Notes: The maximum eigenvalue and trace statistics apply a small-sample correction to Johansen's (1991) statistics, replacing $\mathrm{T}$ by $\mathrm{T}-\mathrm{nm}$, where $\mathrm{T}=$ number observations, $\mathrm{n}=$ number of variables, $\mathrm{m}=$ number of lags. The system variables are: $(\mathrm{G} / \mathrm{Y}), \mathrm{y}, \mathrm{r} 1, \mathrm{~mm}$, and $\mathrm{h}$. The sample period is 1889-1992. Lag length in the VAR is displayed in the top row. Critical values are from Osterwald-Lenum (1992). 
Table 4: Variance Decompositions of the Real Exchange Rate

\section{The VDC of $\Delta(\mathbf{r} 1)$}

\begin{tabular}{|c|c|c|c|c|c|c|}
\hline Horizon & $\epsilon^{\mathrm{g}}$ & $\epsilon^{\mathrm{S}}$ & $\epsilon^{\mathrm{D}}$ & $\epsilon^{\mathrm{mm}}$ & $\epsilon^{\mathrm{h}}$ & $\epsilon^{\mathrm{mm}}+\epsilon^{\mathrm{h}}$ \\
\hline \multirow[t]{2}{*}{1} & 13.3 & 0.50 & 45.6 & 26.1 & 14.5 & 40.6 \\
\hline & $\left(\begin{array}{ll}1.34 & 34.0\end{array}\right)$ & $\left(\begin{array}{ll}0.25 & 14.1\end{array}\right)$ & $\left(\begin{array}{ll}12.4 & 57.2\end{array}\right)$ & $\left(\begin{array}{ll}3.81 & 45.7\end{array}\right)$ & $\left(\begin{array}{ll}2.47 & 28.9\end{array}\right)$ & $\left(\begin{array}{ll}16.0 & 61.8\end{array}\right)$ \\
\hline \multirow[t]{2}{*}{2} & 11.6 & 3.93 & 40.3 & 26.4 & 17.5 & 43.9 \\
\hline & $\left(\begin{array}{ll}2.65 & 30.3\end{array}\right)$ & $\left(\begin{array}{ll}2.01 & 16.8\end{array}\right)$ & $\left(\begin{array}{ll}12.8 & 51.5\end{array}\right)$ & $\left(\begin{array}{ll}6.21 & 41.4\end{array}\right)$ & $\left(\begin{array}{ll}7.70 & 28.9\end{array}\right)$ & $\left(\begin{array}{ll}21.6 & 61.2\end{array}\right)$ \\
\hline \multirow[t]{2}{*}{5} & 10.3 & 4.18 & 39.1 & 26.1 & 20.3 & 46.4 \\
\hline & $\left(\begin{array}{ll}5.25 & 26.5\end{array}\right)$ & (4.19 17.2) & $\left(\begin{array}{ll}15.0 & 44.9\end{array}\right)$ & $\left(\begin{array}{ll}8.57 & 38.6\end{array}\right)$ & $\left(\begin{array}{ll}9.08 & 30.8\end{array}\right)$ & $\left(\begin{array}{ll}25.9 & 59.1\end{array}\right)$ \\
\hline \multirow[t]{2}{*}{20} & 13.4 & 5.76 & 36.9 & 25.0 & 18.9 & 43.9 \\
\hline & $\left(\begin{array}{ll}9.85 & 26.8\end{array}\right)$ & $\left(\begin{array}{ll}7.26 & 18.7\end{array}\right)$ & (15.5 37.4$)$ & $\left(\begin{array}{ll}11.8 & 33.7\end{array}\right)$ & $\left(\begin{array}{ll}10.3 & 26.1\end{array}\right)$ & $\left(\begin{array}{ll}29.1 & 52.6\end{array}\right)$ \\
\hline
\end{tabular}

The VDC of (r1)

\begin{tabular}{|c|c|c|c|c|c|c|}
\hline Horizon & $\epsilon^{\mathrm{g}}$ & $\epsilon^{\mathrm{S}}$ & $\epsilon^{\mathrm{D}}$ & $\epsilon^{\mathrm{mm}}$ & $\epsilon^{\mathrm{h}}$ & $\epsilon^{\mathrm{mm}}+\epsilon^{\mathrm{h}}$ \\
\hline \multirow[t]{2}{*}{1} & 13.3 & 0.50 & 45.6 & 26.1 & 14.5 & 40.6 \\
\hline & $(1.34 \quad 34.0)$ & $\left(\begin{array}{ll}0.25 & 14.1\end{array}\right)$ & (12.4 57.2) & $\left(\begin{array}{ll}3.81 & 45.7\end{array}\right)$ & $\left(\begin{array}{ll}2.47 & 28.9\end{array}\right)$ & $\left(\begin{array}{ll}16.0 & 61.8\end{array}\right)$ \\
\hline \multirow[t]{2}{*}{2} & 12.3 & 3.27 & 45.1 & 32.4 & 6.82 & 39.2 \\
\hline & $\left(\begin{array}{ll}1.98 & 33.8\end{array}\right)$ & (0.96 17.6) & $\left(\begin{array}{ll}13.0 & 59.1\end{array}\right)$ & $\left(\begin{array}{ll}5.81 & 49.8\end{array}\right)$ & $\left(\begin{array}{ll}2.01 & 16.4\end{array}\right)$ & $\left(\begin{array}{ll}13.9 & 60.0\end{array}\right)$ \\
\hline \multirow[t]{2}{*}{5} & 14.8 & 5.62 & 47.3 & 27.9 & 4.32 & 32.2 \\
\hline & $\left(\begin{array}{ll}3.82 & 35.6\end{array}\right)$ & $\left(\begin{array}{ll}1.98 & 22.1\end{array}\right)$ & (16.6 58.3) & $\left(\begin{array}{ll}6.01 & 42.8\end{array}\right)$ & $\left(\begin{array}{ll}2.73 & 10.3\end{array}\right)$ & $\left(\begin{array}{ll}12.3 & 49.8\end{array}\right)$ \\
\hline \multirow[t]{2}{*}{20} & 34.0 & 2.77 & 51.4 & 9.21 & 2.53 & 11.7 \\
\hline & $\left(\begin{array}{ll}14.1 & 55.3\end{array}\right)$ & $\left(\begin{array}{ll}2.53 & 15.5\end{array}\right)$ & (21.0 61.6) & $\left(\begin{array}{ll}3.38 & 15.2\end{array}\right)$ & $\left(\begin{array}{ll}1.58 & 6.03\end{array}\right)$ & $\left(\begin{array}{ll}6.26 & 20.8\end{array}\right)$ \\
\hline
\end{tabular}

Notes: The variance decomposition results indicate the percentage of the forecast error variance of $\Delta(\mathrm{r})$ or (r) that is due to each shock at the 1-year, 2-year, 5-year, and 20-year horizons. By construction, the contributions of $\epsilon^{\mathrm{mm}}$ and $\epsilon^{\mathrm{h}}$ to the variance of (r) go to zero asymptotically. Lag length is 8 . In parenthesis are the $16^{\text {th }}$ - and $84^{\text {th }}$-percentiles (corresponding to a one standard deviation confidence interval) of the distribution of variance decompositions from 1,000 simulations of the model, calculated using the Monte Carlo procedure in RATS. 
Table 5: Real Exchange Rate VDCs in Alternative Models

\section{The VDC of $\left(\mathbf{r}_{\mathbf{j}}\right)$}

\begin{tabular}{cccccc} 
Case & $\epsilon^{\mathrm{g}}$ & $\epsilon^{\mathrm{S}}$ & $\epsilon^{\mathrm{D}}$ & $\epsilon^{\mathrm{mm}}$ & $\epsilon^{\mathrm{h}}$ \\
\hline \hline 0 & $13.6,12.6,34.5$ & $0.55,3.37,2.81$ & $45.3,44.8,51.1$ & $26.0,32.3,9.15$ & $14.7,6.92,2.51$ \\
1 & $12.5,19.1,47.3$ & $0.20,0.72,2.64$ & $39.8,45.2,38.1$ & $19.1,17.5,6.07$ & $28.4,17.5,5.86$ \\
2 & $0.76,0.45,3.26$ & $3.54,4.65,13.2$ & $48.4,48.9,71.7$ & $26.4,25.4,6.75$ & $20.9,20.6,5.09$ \\
3 & $12.2,16.7,28.4$ & $0.51,0.39,7.79$ & $45.9,46.9,56.5$ & $25.4,27.5,5.84$ & $16.0,8.51,1.48$ \\
$4^{\mathrm{a}}$ & $0.35,0.41,----$ & $15.8,25.2,----$ & $62.9,62.3,----$ & $7.15,5.03,----$ & $13.8,6.98,----$ \\
$5^{\mathrm{b}}$ & $23.8,20.4,5.46$ & $0.10,1.04,6.09$ & $52.9,56.4,79.2$ & $14.0,18.2,6.55$ & $9.14,3.99,2.74$ \\
$6^{\mathrm{c}}$ & $----{ }^{\mathrm{c}}$ & $14.1,23.2,----$ & $----{ }^{c}$ & $8.53,6.27,----$ & $14.9,7.66,----$ \\
$7^{\mathrm{d}}$ & $13.3,12.3,34.0$ & $2.78,7.23,3.84$ & $43.2,41.2,50.4$ & $26.1,32.4,9.21$ & $14.5,6.82,2.53$ \\
$8^{\mathrm{e}}$ & $0.13,0.35,1.51$ & $18.0,11.9,5.66$ & $63.2,68.4,86.2$ & $3.87,6.25,4.77$ & $14.8,13.1,1.86$ \\
$9^{\mathrm{f}}$ & $2.40,2.48,3.56$ & $9.68,16.6,22.1$ & $35.9,42.9,62.3$ & $51.4,35.5,10.0$ & $0.91,2.55,1.98$ \\
\hline \hline
\end{tabular}

Notes: Each cell contains the VDC at horizons 1, 2, and 20. Case 0 is repeated from Table 4; the other cases differ from Case 0 by,

Case $1=r 2$, the GDP deflator-based real exchange rate, replacing $\mathrm{r}$;

Case $2=r 3$, the relative price of non-tradeables to tradeables, replacing $\mathrm{r} 1$;

Case 3 = VAR with 5 lags instead of 7 ;

Case $4^{\mathrm{a}}=$ VAR with $\mathrm{r} 1$ assumed to be trend-stationary, new ordering;

Case $5^{\mathrm{b}}=$ VAR with $(\mathrm{G} / \mathrm{Y})$ assumed to be stationary, new ordering;

Case $6^{\mathrm{c}}=$ VAR with $\mathrm{r} 1$ and $(\mathrm{G} / \mathrm{Y})$ assumed to be trend-stationary, new ordering;

Case $7^{\mathrm{d}}=$ VAR with $\Delta(\mathrm{r} 1)$ placed ahead of $\Delta(\mathrm{y})$ in the ordering;

Case $8^{\mathrm{e}}=$ VAR with $\Delta(\mathrm{mm})$ placed ahead of $\Delta(\mathrm{r} 1)$ in the ordering;

Case $9^{\mathrm{f}}=\mathrm{VAR}$ with $\Delta(\mathrm{G} / \mathrm{Y})$ placed last in the ordering.

(a) Long-run effects on trend-stationary $\mathrm{r} 1$ are not applicable; the ordering of variables is $\{\Delta(\mathrm{G} / \mathrm{Y}), \Delta(\mathrm{y})$, $\Delta(\mathrm{mm}), \Delta(\mathrm{h}), \mathrm{r} 1\}$.

(b) The ordering of variables is $\{\Delta(\mathrm{y}), \Delta(\mathrm{r} 1), \Delta(\mathrm{mm}), \Delta(\mathrm{h}),(\mathrm{G} / \mathrm{Y})\}$.

(c) The ordering of variables is $\{\Delta(\mathrm{y}), \Delta(\mathrm{mm}), \Delta(\mathrm{h}),(\mathrm{G} / \mathrm{Y}), \mathrm{r} 1\} ; \epsilon^{\mathrm{g}}$ and $\epsilon^{\mathrm{D}}$ are transitory disturbances which are not identified separately from one another. The combined contribution of these two shocks is $62.4,63.0$, and 27.9, at horizons 1, 2, and 20, respectively. Long-run effects on trend-stationary r1 are not applicable.

(d) The ordering of variables is $\{\Delta(\mathrm{G} / \mathrm{Y}), \Delta(\mathrm{r} 1), \Delta(\mathrm{y}), \Delta(\mathrm{mm}), \Delta(\mathrm{h})\}$;

(e) The ordering of variables is $\{\Delta(\mathrm{G} / \mathrm{Y}), \Delta(\mathrm{y}), \Delta(\mathrm{mm}), \Delta(\mathrm{r} 1), \Delta(\mathrm{h})\}$;

(f) The ordering of variables is $\{\Delta(\mathrm{y}), \Delta(\mathrm{r} 1), \Delta(\mathrm{mm}), \Delta(\mathrm{h}), \Delta(\mathrm{G} / \mathrm{Y})\}$. 
Table 6: Tests for VAR Lag Length and Cointegration (systems with CPI-based real exchange rates)

A. Likelihood Ratio Tests for Lag Length

\begin{tabular}{|c|c|c|c|c|c|c|c|c|}
\hline & Case & 8 vs. 7 & 7 vs. 6 & 6 vs. 5 & 5 vs. 4 & 4 vs. 3 & 3 vs. 2 & $*$ \\
\hline \multirow{3}{*}{ U.K. } & $\begin{array}{l}\text { CG model, } \\
\text { CG sample }\end{array}$ & $\begin{array}{l}4.66 \\
(.86)\end{array}$ & $\begin{array}{l}9.07 \\
(.43)\end{array}$ & $\begin{array}{l}2.44 \\
(.98)\end{array}$ & $\begin{array}{l}16.5 \\
(.06)\end{array}$ & $\begin{array}{l}21.2 \\
(.01)\end{array}$ & $\begin{array}{l}9.89 \\
(.36)\end{array}$ & \\
\hline & $\begin{array}{l}\text { CG model, } \\
\text { My sample }\end{array}$ & $\begin{array}{l}8.58 \\
(.48)\end{array}$ & $\begin{array}{l}6.50 \\
(.69)\end{array}$ & $\begin{array}{l}11.0 \\
(.28)\end{array}$ & $\begin{array}{l}20.5 \\
(.01)\end{array}$ & $\begin{array}{l}12.1 \\
(.21)\end{array}$ & $\begin{array}{l}14.0 \\
(.12)\end{array}$ & \\
\hline & $\begin{array}{l}\text { My model, } \\
\text { CG sample }\end{array}$ & $\begin{array}{l}27.0 \\
(.36)\end{array}$ & $\begin{array}{l}39.5 \\
(.03)\end{array}$ & $\begin{array}{l}31.9 \\
(.16)\end{array}$ & $\begin{array}{l}38.7 \\
(.04)\end{array}$ & $\begin{array}{l}90.7 \\
(.00)\end{array}$ & $\begin{array}{l}77.6 \\
(.00)\end{array}$ & $\begin{array}{l}67.7 \\
(.05)\end{array}$ \\
\hline \multirow{2}{*}{ Canada } & $\begin{array}{l}\text { CG model, } \\
\text { CG sample }\end{array}$ & $\begin{array}{l}14.0 \\
(.12)\end{array}$ & $\begin{array}{l}10.8 \\
(.29)\end{array}$ & $\begin{array}{l}15.9 \\
(.07)\end{array}$ & $\begin{array}{l}6.67 \\
(.67)\end{array}$ & $\begin{array}{l}13.7 \\
(.13)\end{array}$ & $\begin{array}{l}13.7 \\
(.14)\end{array}$ & \\
\hline & $\begin{array}{l}\text { My model, } \\
\text { CG sample }\end{array}$ & $\begin{array}{l}29.6 \\
(.24)\end{array}$ & $\begin{array}{l}44.6 \\
(.01)\end{array}$ & $\begin{array}{l}36.5 \\
(.06)\end{array}$ & $\begin{array}{l}37.3 \\
(.05)\end{array}$ & $\begin{array}{l}59.2 \\
(.00)\end{array}$ & $\begin{array}{l}25.2 \\
(.45)\end{array}$ & $\begin{array}{c}106.4 \\
(.01)\end{array}$ \\
\hline Germany & $\begin{array}{l}\text { CG model, } \\
\text { CG sample }\end{array}$ & $\begin{array}{l}14.6 \\
(.10)\end{array}$ & $\begin{array}{l}12.0 \\
(.21)\end{array}$ & $\begin{array}{l}4.82 \\
(.85)\end{array}$ & $\begin{array}{l}4.24 \\
(.89)\end{array}$ & $\begin{array}{l}9.18 \\
(.42)\end{array}$ & $\begin{array}{l}26.2 \\
(.00)\end{array}$ & \\
\hline Japan & $\begin{array}{l}\text { CG model, } \\
\text { CG sample }\end{array}$ & $\begin{array}{l}15.3 \\
(.08)\end{array}$ & $\begin{array}{l}5.56 \\
(.78)\end{array}$ & $\begin{array}{l}6.05 \\
(.74)\end{array}$ & $\begin{array}{l}7.87 \\
(.55)\end{array}$ & $\begin{array}{l}18.0 \\
(.04)\end{array}$ & $\begin{array}{l}4.34 \\
(.89)\end{array}$ & \\
\hline
\end{tabular}

B. Trace Tests of Cointegrating Rank (U.K. and Canada)

U.K. Systems

Canadian Systems

\begin{tabular}{c|cccc|cccc}
\hline \hline $\begin{array}{c}\mathrm{H}_{0}: \mathrm{CI} \\
\text { rank= } \\
\mathrm{p}\end{array}$ & $\begin{array}{c}\text { CG model } \\
\text { CG sample } \\
\text { (5 lags) }\end{array}$ & $\begin{array}{c}\text { My model } \\
\text { CG } \\
\text { sample } \\
\text { (6 lags) }\end{array}$ & $\begin{array}{c}\text { My model } \\
\text { CG sample } \\
\text { (8 lags) }\end{array}$ & $\begin{array}{c}\text { CG model } \\
\text { My } \\
\text { sample } \\
\text { 6 lags) }\end{array}$ & $\begin{array}{c}\text { CG model } \\
\text { CG sample } \\
\text { (5 lags) }\end{array}$ & $\begin{array}{c}\text { CG model } \\
\text { CG sample } \\
\text { (7 lags) }\end{array}$ & $\begin{array}{c}\text { My model } \\
\text { CG sample } \\
\text { (5 lags) }\end{array}$ & $\begin{array}{c}\text { My model } \\
\text { CG sample } \\
\text { (8 lags) }\end{array}$ \\
\hline $\mathrm{p}=0$ & 23.3 & $68.8^{*}$ & 56.5 & 14.3 & $35.6^{* *}$ & $35.8^{* *}$ & 63.3 & 60.8 \\
$\mathrm{p} \leq 1$ & 10.4 & 40.6 & 30.0 & 6.61 & 9.71 & 11.1 & 40.1 & 37.2 \\
$\mathrm{p} \leq 2$ & $4.17^{*}$ & 19.7 & 15.6 & 2.04 & 2.99 & $4.72^{*}$ & 17.7 & 18.9 \\
$\mathrm{p} \leq 3$ & --- & 7.40 & 8.24 & --- & --- & -- & 6.58 & 8.30 \\
$\mathrm{p} \leq 4$ & --- & 0.91 & 2.95 & --- & --- & --- & 2.34 & 2.41 \\
\hline \hline
\end{tabular}

Notes: "CG Model" indicates that the variables in the VAR are $\{\Delta \mathrm{y}, \Delta \mathrm{r}, \pi\}$ as in Clarida and Gali; "My Model" refers to the variables in my 5-variable VAR, $\{\Delta(\mathrm{G} / \mathrm{Y}), \Delta \mathrm{y}, \Delta \mathrm{r} 1, \Delta \mathrm{mm}, \Delta \mathrm{h}\}$; "CG Sample" indicates the use of quarterly data from 1974:3 to 1992:4, while "My Sample" is annual data from 1889 to 1992. In Part A of the table, LR denotes the likelihood ratio statistic used to test the null hypothesis that the $\mathrm{j}+1$ lags in each VAR equation are zero. The marginal significance level of the LR statistic is in parenthesis. In (*), the test is a lag length of 7 versus 5 for the U.K., and 7 versus 4 for Canada. The trace test statistics of Part B apply a simple small-sample correction to Johansen's (1991) statistics. The lag length in the VAR, displayed in the top row, refers to the number of lagged levels of each variable used. The $95 \%$ critical values are $68.5,47.2,29.7,15.4,3.8$. A * (**) denotes significant at the $5 \%$ (1\%) level. 
$-34-$ 
Table 7: Encompassing (VDCs of Real Exchange Rate Changes)

A. Estimating Clarida and Gali's Three-Variable Model on Clarida and Gali's Data and Sample Period

\begin{tabular}{|c|c|c|c|c|}
\hline Country & Case & Supply Shock & Demand Shock & Nominal Shock \\
\hline \multirow{4}{*}{ U.K. } & (CG) & $0.50 / 5.50 / 6.10$ & 97.3 / $91.9 / 91.1$ & $2.20 / 2.50 / 2.80$ \\
\hline & (1) & $0.10 / 5.46 / 7.09$ & 99.9 / 89.5 / 86.6 & $0.03 / 5.06 / 6.32$ \\
\hline & (2) & $0.05 / 6.22$ / 8.61 & 96.9 / 87.4 / 84.7 & $3.08 / 6.40 / 6.71$ \\
\hline & (3) & $0.21 / 8.55 / 9.25$ & 97.4 / 89.0 / 88.2 & $2.40 / 2.47 / 2.55$ \\
\hline \multirow{4}{*}{ Canada } & (CG) & $2.20 / 4.50 / 4.30$ & $97.0 / 94.3$ / 93.2 & $0.70 / 1.20 / 2.50$ \\
\hline & (1) & $0.70 / 3.54 / 4.43$ & 98.4 / 93.5 / 92.2 & $0.92 / 2.97 / 3.39$ \\
\hline & (2) & 19.9 / $25.4 / 24.3$ & $80.0 / 74.0 / 70.9$ & $0.03 / 0.65 / 4.79$ \\
\hline & (3) & 11.4 / $13.2 / 13.2$ & 88.3 / 83.3 / 82.0 & $0.30 / 3.49 / 4.77$ \\
\hline \multirow[t]{4}{*}{ Germany } & (CG) & $0.70 / 4.60 / 10.4$ & $51.8 / 50.3 / 48.5$ & $47.4 / 45.0 / 41.1$ \\
\hline & (1) & $14.6 / 13.9 / 13.4$ & 49.8 / 48.2 / 46.9 & $35.6 / 37.9 / 39.7$ \\
\hline & (2) & $6.59 / 6.38 / 6.65$ & $70.0 / 65.1 / 61.9$ & $23.4 / 28.5 / 31.5$ \\
\hline & (3) & $18.8 / 18.5 / 16.9$ & 35.8 / 35.4 / 36.9 & 45.4 / 46.2 / 46.2 \\
\hline \multirow[t]{4}{*}{ Japan } & (CG) & $0.90 / 3.40 / 3.60$ & $63.1 / 62.7 / 61.2$ & $35.9 / 33.9 / 35.2$ \\
\hline & (1) & $9.99 / 10.2 / 12.1$ & $43.7 / 44.2 / 42.0$ & $46.3 / 45.5 / 45.8$ \\
\hline & (2) & $5.32 / 7.99 / 10.3$ & $57.2 / 56.0 / 44.7$ & $37.5 / 36.0 / 45.0$ \\
\hline & (3) & $11.0 / 11.0 / 13.1$ & 40.4 / 41.2 / 39.2 & $48.6 / 47.8 / 47.7$ \\
\hline
\end{tabular}

Notes: Entries indicate the percentage of the forecast error variance of $\Delta(\mathrm{r})$ that is due to each shock at the 1quarter, 4-quarter, and 20-quarter horizons. The sample period is 1974:3-1992:4. For each country, the first row of results (with (CG) following the country name) indicates that the estimates are taken from Table 4 of Clarida and Gali (1994). My replication is in the next row, labeled case (1). A lag length of 4 is used in these VARs. The row labeled case (2) for each country presents estimates using an alternative lag length chosen based upon likelihood ratio tests: 5 lags for the U.K., 6 lags for Canada, 3 for Germany, and 8 for Japan. The row labeled case (3) uses GDP deflators instead of CPIs in computing the real exchange rate and inflation; 4 lags are included in these VARs.

B. Estimating Clarida and Gali's Three-Variable Model on My Data and Sample Period

\begin{tabular}{cccc} 
System & Supply Shock & Demand Shock & Nominal Shock \\
\hline r1, 4 lags & $0.72 / 2.94 / 3.63$ & $94.9 / 90.5 / 88.9$ & $4.39 / 6.57 / 7.45$ \\
r1, LR lags & $9.10 / 11.9 / 13.3$ & $79.3 / 74.8 / 69.7$ & $11.6 / 13.3 / 16.9$ \\
r2, 4 lags & $0.01 / 3.28 / 5.05$ & $80.8 / 69.0 / 67.0$ & $19.2 / 27.8 / 27.9$ \\
r2, LR lags & $2.30 / 2.95 / 7.65$ & $80.0 / 73.7 / 65.4$ & $17.6 / 23.4 / 26.9$ \\
\hline \hline
\end{tabular}

Notes: Entries indicate the percentage of the forecast error variance of $\Delta(\mathrm{r})$ that is due to each shock at the 1-year, 5 -year (20-quarters), and 20-year horizons. R1 is the WPI-based real exchange rate, and $\mathrm{r} 2$ is the GDP deflatorbased real exchange rate. The VAR lag length of chosen by the likelihood ratio test is 5 in each case. The sample period is $1889-1992$. 


\section{The VDC of $(\Delta \mathbf{r})$}

\begin{tabular}{cccccc} 
Case & $\epsilon^{\mathrm{g}}$ & $\epsilon^{\mathrm{S}}$ & $\epsilon^{\mathrm{D}}$ & $\epsilon^{\mathrm{mm}}$ & $\epsilon^{\mathrm{h}}$ \\
\hline \hline U.K. $^{1}$ & $14.8 / 16.4 / 16.5$ & $2.42 / 8.47 / 11.5$ & $48.8 / 44.1 / 41.9$ & $27.8 / 24.7 / 23.5$ & $6.07 / 6.32 / 6.62$ \\
U.K. $^{2}$ & $14.8 / 13.7 / 12.3$ & $0.02 / 5.84 / 9.81$ & $28.6 / 30.6 / 27.3$ & $42.4 / 34.8 / 32.1$ & $14.2 / 15.1 / 18.5$ \\
U.K. $^{3}$ & $0.10 / 3.73 / 4.08$ & $0.04 / 0.56 / 3.87$ & $79.4 / 65.9 / 61.5$ & $20.5 / 24.9 / 24.9$ & $0.01 / 4.94 / 5.68$ \\
U.K. $^{4}$ & $0.04 / 5.55 / 6.83$ & $0.19 / 1.64 / 6.54$ & $73.0 / 59.1 / 54.3$ & $24.7 / 29.2 / 26.5$ & $2.15 / 4.49 / 5.79$ \\
Canada $^{1}$ & $49.4 / 40.9 / 38.0$ & $0.43 / 3.07 / 4.07$ & $47.8 / 52.2 / 51.0$ & $2.06 / 2.29 / 4.76$ & $0.32 / 1.49 / 2.18$ \\
Canada $^{2}$ & $57.1 / 43.8 / 36.3$ & $0.50 / 9.74 / 12.3$ & $28.5 / 36.9 / 38.3$ & $13.9 / 7.88 / 10.8$ & $0.00 / 1.68 / 2.31$ \\
Canada $^{3}$ & $36.4 / 37.9 / 38.0$ & $4.94 / 3.54 / 5.53$ & $51.4 / 45.2 / 39.7$ & $6.15 / 8.72 / 11.6$ & $1.12 / 4.70 / 5.22$ \\
Canada $^{4}$ & $56.9 / 46.1 / 41.6$ & $1.84 / 8.22 / 14.5$ & $32.5 / 32.1 / 23.0$ & $8.42 / 11.2 / 15.1$ & $0.32 / 2.35 / 5.83$
\end{tabular}

Notes: Entries indicate the percentage of the forecast error variance of $\Delta(\mathrm{r})$ that is due to each shock at the 1-quarter, 4-quarter, and 20-quarter horizons. The sample period is 1974:3-1992:4. Lags lengths are based upon likelihood ratio tests. A description of the cases is as follows:

U.K. ${ }^{1}=$ CPI-based real exchange rate, 4 lags in the VAR;

U.K. ${ }^{2}=$ CPI-based real exchange rate, 5 lags in the VAR;

U.K. ${ }^{3}=$ GDP deflator-based real exchange rate, 4 lags in the VAR;

U.K. ${ }^{4}=$ GDP deflator-based real exchange rate, 5 lags in the VAR;

Canada ${ }^{1}=\mathrm{CPI}$-based real exchange rate, 4 lags in the VAR;

Canada $^{2}=$ CPI-based real exchange rate, 7 lags in the VAR;

Canada ${ }^{3}=$ GDP deflator-based real exchange rate, 4 lags in the VAR;

Canada $^{4}=$ GDP deflator-based real exchange rate, 8 lags in the VAR; 


\section{Appendix to:}

Monetary Shocks and Real Exchange Rates

John H. Rogers

Federal Reserve Board

May 1998

1. Data Appendix

2. Appendix A: General-equilibrium optimizing model used to interpret the structural shocks

3. Appendix B: Identifying the VAR when the Real Exchange Rate is I(0)

4. Tests for Cointegration and Lag Length in the Model with r2 or r3 


\section{DATA APPENDIX}

The sources for the data on prices, output, and government spending are Mitchell (1988) for the United Kingdom and Kendrick (1961) for the United States. The exchange rate series is also taken from Mitchell (1988), while the money supply and monetary base data are taken from Friedman and Schwartz (1982). Updates are from Britain's Central Statistical Office, and various issues of the Survey of Current Business for the United States.

The series are created as follows:

$(\mathrm{g} / \mathrm{y})=$ real government consumption as a share of real GNP, U.K. less U.S.;

$\mathrm{y}=\log$ of real GNP, U.K. less U.S. (annual average);

$\mathrm{r} 1(\mathrm{r} 2)=\log$ of real exchange rate, $\mathrm{S}$ - P1 (S - P2), (annual averages) where

$\mathrm{S}=\log$ of the nominal exchange rate in pounds per dollar

$\mathrm{P} 1=\log$ of the wholesale price index, U.K. relative to U.S.

$\mathrm{P} 2=\log$ of the GNP deflator, U.K. relative to U.S.;

$\mathrm{r} 3=\log$ of the real exchange rate, $\mathrm{P}_{\mathrm{N}}-\mathrm{P}_{\mathrm{T}}$, where

$\mathrm{P}_{\mathrm{N}}=$ price of non-traded goods, as proxied by the government expenditure deflator (U.K./U.S.),

$\mathrm{P}_{\mathrm{T}}=$ price of traded goods, as proxied by $\mathrm{P} 1$;

$\mathrm{mm}=\log$ of money multiplier, $\log (\mathrm{M} / \mathrm{H}), \mathrm{U} . \mathrm{K}$. less U.S., where

$\mathrm{M}=$ nominal $\mathrm{M} 2$ money stock (mid-year observation)

$\mathrm{H}=$ nominal monetary base (mid-year observation);

$\mathrm{h}=\log$ of real monetary base, $\log \left(\mathrm{H} / \mathrm{P}_{\mathrm{N}}\right)$, U.K. less U.S..

\section{APPENDIX A: Interpreting the Shocks in the VAR Models: An Illustrative Long-Run Model}

In order to illustrate how the residuals may be interpreted as fundamental structural shocks, I develop the following general-equilibrium optimizing model. The point of departure is Rogoff (1992) [see also section 3 of Froot and Rogoff (1995)], who explores the predictions of theoretical models concerning the types of shocks that will affect the real exchange rate. First, in the classic BalassaSamuelson model with perfect competition, perfect mobility of factors across sectors and internationally, and a small country setting, only productivity shocks will affect the real exchange rate. However, demand factors do have an impact in Rogoff's "fixed factor, open capital markets" model. More generally, there is role for demand factors in the short run (and possibly the long run) if the country is "large"; if there is some capital immobility internationally; if capital and labor are not instantaneously mobile across sectors domestically; and if there are increasing returns to scale (demand factors affect the real exchange rate in the long run if there is a fixed factor, such as land, which can be transferred across sectors, thus implying increasing returns to the mobile factors).

In the model that follows, I add two things to Rogoff's analysis: taste shocks, in the form of a disturbance to traded goods consumption, and money, via a cash-in-advance constraint. It should be noted that, like Rogoff, I specify a small country model. The U.K. and U.S. are not small economies. An alternative way of thinking about how the model produces the zero restrictions in (5) is to assume that equations analogous to the ones presented below hold for a "foreign" country. Finally, it should be noted that, in linking the theory to the empirical work, I rely only on particular steady-state features of the model as described below. 
Traded and non-traded goods are produced according to the production technology,

$$
\begin{aligned}
y_{T t} & =A_{T t} L_{T t}^{\omega_{T}} K_{T t}^{1-\omega_{T}} \\
y_{N t} & =A_{N t} L_{N t}^{\omega_{N}} K_{N t}^{1-\omega_{N}}
\end{aligned}
$$

where $y_{i t}$ is output in sector $I(I=T, N), L_{i t}$ and $K_{i t}$ represent the labor and capital input into $y_{i t}$ and $A_{i t}$ is a stochastic productivity shock in sector I. I will abstract from considering growth in, or depreciation of, the inputs, meaning that $\mathrm{L}$ and $\mathrm{K}$ are unchanged in steady state. Assume that $\mathrm{L}$ and $\mathrm{K}$ are immobile across sectors, although, as noted above, this is not strictly necessary for there to be a role for factors other than productivity.

There is a representative agent with time-separable utility over consumption,

$$
V_{t}=E_{t} \sum_{s=0}^{\infty} \beta^{s-t}\left[\frac{\left(c_{N s}^{\alpha} \theta_{s} c_{T s}^{1-\alpha}\right)^{1-\gamma}}{1-\gamma}\right]
$$

where $\mathrm{E}$ is the expectations operator, $\beta$ is the subjective discount rate, $\mathrm{c}_{\mathrm{it}}$ is consumption of good I at time $\mathrm{t}$, and $\theta_{\mathrm{t}}$ is a shift parameter that captures changes in preferences toward the traded good.

Assume that domestic agents hold domestic money $\mathrm{M}$ and foreign money $\mathrm{M}^{*}$. With $\mathrm{P}_{\mathrm{N}}\left(\mathrm{P}_{\mathrm{T}}\right)$ denoting the price of the non-traded (traded) good, and $\mathrm{Q}=\mathrm{P}_{\mathrm{N}} / \mathrm{P}_{\mathrm{T}}$, we can define real money balances $\mathrm{m}$ $=\mathrm{M} / \mathrm{P}_{\mathrm{N}}$ and $\mathrm{m}^{*}=\mathrm{M}^{*} / \mathrm{P}_{\mathrm{T}}$, so that domestic real balances in terms of tradeables is given by $\tilde{\mathrm{m}}=\mathrm{Qm}=$ $\mathrm{M} / \mathrm{P}_{\mathrm{T}}$. In this case, we add to the model the individual's budget constraint,

$$
\tilde{m}_{t+1}+m_{t+1}^{*}=z_{t}-c_{T t}-Q_{t} c_{N t}-\tilde{\pi}_{t} \tilde{m}_{t}-\pi_{t}^{*} m_{t}^{*}-g_{T t}-Q_{t} g_{N t}
$$

where $\mathrm{z}$ is total income from domestic production (in terms of tradeables), $\pi=\Delta \mathrm{P}_{\mathrm{N}} / \mathrm{P}_{\mathrm{N}}$, and $\pi^{*}=\Delta \mathrm{P}_{\mathrm{T}} / \mathrm{P}_{\mathrm{T}}$. I assume that government consumption of traded and non-traded goods, $\mathrm{g}_{\mathrm{T}}$ and $\mathrm{g}_{\mathrm{N}}$ respectively, is financed by taxes (there is no debt), and that the representative agent integrates the government budget constraint into her own.

It is also assumed that the representative agent needs to hold various amounts of domestic and foreign real balances in order to purchase consumption goods,

$$
c_{T t}+Q_{t} c_{N t} \leq f\left(\tilde{m_{t}}, m_{t}^{*}\right)
$$

For the sake of tractability, I assume that the money demand function $\mathrm{f}(\mathrm{)})$ takes the form,

$$
f\left(\tilde{m}_{t}, m_{t}^{*}\right)=\tilde{\rho} \tilde{m}_{t}\left(m_{t}^{*}\right)^{1-\phi}
$$

where $\phi(1-\phi)$ is the share of total money balances held in the form of domestic (foreign) money, and $\rho$ denotes the fraction devoted to "cash goods", where $0<\rho \leq 1$. 
The agent's problem is to maximize (A2) subject to (A3)-(A5). The Hamiltonian is written,

$$
\begin{aligned}
& H=E_{t} \sum_{s=0}^{\infty} \beta^{s-t}\left[\frac{\left(c_{N s} \theta_{s} c_{T s}\right)^{1-\gamma}}{1-\gamma}\right]+\lambda_{1}\left[\tilde{\rho} \tilde{m}_{s}\left(m_{s}^{*}\right)^{1-\phi}-c_{T s}-Q_{s} c_{N s}\right] \\
& +\lambda_{2}\left[z_{s}-\tilde{m}_{s+1}-m_{s+1}^{*}-c_{T s}-Q_{s} c_{N s}-\pi_{s} \tilde{m}_{s}-\pi_{s}^{*} m_{s}^{*}-g_{T s}-Q_{s} g_{N s}\right]
\end{aligned}
$$

Using the first-order conditions for both traded and non-traded goods consumption gives us,

$$
Q_{t}=\theta_{t}\left(\frac{\alpha}{1-\alpha}\right)\left(\frac{c_{T t}}{c_{N t}}\right)
$$

while the first-order conditions for domestic and foreign money balances imply,

$$
\tilde{m}_{t}=\left(\frac{\phi}{1-\phi}\right) m_{t}^{*}\left(\frac{\pi_{t}^{*}}{\pi_{t}}\right)
$$

To derive an expression for domestic real balances, rewrite the cash-in-advance constraint as,

$$
\frac{c_{T t}}{Q_{t}}+c_{N t}=\rho m_{t}\left(\frac{m_{t}^{*}}{\sim}\right)^{1-\phi}
$$

where it will be recalled that $\mathrm{m}_{\mathrm{t}}=\tilde{\mathrm{m}}_{\mathrm{t}} / \mathrm{Q}_{\mathrm{t}}$. Also, note that (A6) can be rewritten $\mathrm{c}_{\mathrm{T}} / \mathrm{Q}=\theta^{-1} \mathrm{c}_{\mathrm{N}}[(1-\alpha) / \alpha]$, so that this and (A7) substituted into (A8) becomes, upon rearranging,

$$
m_{t}=\theta_{t}^{-1}\left(\frac{1}{\alpha}\right) c_{N t} \rho^{-1}\left[\left(\frac{1-\phi}{\phi}\right)\left(\frac{\pi_{t}}{\pi_{t}^{*}}\right)\right]^{1 / 1-\phi}
$$

Assuming that equilibrium in the non-traded goods market holds,

$$
y_{N t}=c_{N t}+g_{N t}
$$

and imposing the balanced-budget requirement,

$$
g_{N t}=\tau_{t} y_{N t}
$$

then (A9) can be rewritten, 


$$
m_{t}=\vartheta_{t}^{-1}(1 / \alpha) \rho^{-1}\left[\left(\frac{1-\phi}{\phi}\right)\left(\frac{\pi_{t}}{\pi_{t}^{*}}\right)\right]^{\frac{1}{1-\phi}}\left(1-\tau_{t}\right) y_{N t}
$$

Under the assumption that labor and capital constant in steady state, using the steady-state result that $\pi_{\mathrm{t}}=$ $\mu_{\mathrm{t}} \equiv \Delta \mathrm{M}_{\mathrm{t}} / \mathrm{M}_{\mathrm{t}}$, normalizing $\pi^{*}$ to unity, and using equations (A11) and (A1b), equation (A12) can be rewritten in log-differences as,

$$
\Delta \ln \left(m_{t+1}\right)=(1 / \phi) \Delta \ln \left(\mu_{t+1}\right)-\Delta \theta_{t+1}-\Delta \tau_{t+1}+\Delta \ln \left(A_{N, t+1}\right)
$$

Now rewrite (A6), using (A10) and (A11), as

$$
Q_{t}=\theta_{t}\left(\frac{\alpha}{1-\alpha}\right)\left[\frac{c_{T t}}{\left(1-\tau_{t}\right) y_{N t}}\right]
$$

Using the assumption of constant labor and capital in steady state, (A14) becomes in log-differences,

$$
\Delta \ln \left(Q_{t+1}\right)=\Delta \ln \left(c_{T, t+1}\right)+\Delta \theta_{t+1}+\Delta \tau_{t+1}-\Delta \ln \left(A_{N, t+1}\right)
$$

Note that the first-order condition for traded goods consumption implies,

$$
\left(\frac{c_{N t}}{c_{T t}}\right)^{\alpha}\left(c_{N t}^{\alpha} c_{T t}^{1-\alpha}\right)^{-\gamma}=E_{t} \beta\left[\left(\frac{c_{N, t+1}}{c_{T, t+1}}\right)^{\alpha}\left(c_{N, t+1}^{\alpha} c_{T, t+1}^{1-\alpha}\right)^{-\gamma}\right]
$$

Taking logs of both sides of (A16) and rearranging allows us to approximate the equation as,

$$
E_{t} \Delta \ln \left(c_{T, t+1}\right)=\left[\frac{\alpha(1-\gamma)}{\alpha(1-\gamma)+\gamma}\right] E_{t} \Delta \ln c_{N, t+1}
$$

Assuming for simplicity that the expected change in consumption equals the actual change, then (A15) can be rewritten, using (A17) along with (A1b), (A10), and (A11), as:

$$
\Delta \ln \left(Q_{t+1}\right)=\Delta \theta_{t+1}+\Delta \tau_{t+1}\left[\frac{\gamma}{\alpha(1-\gamma)+\gamma}\right]-\Delta \ln \left(A_{N, t+1}\right)\left[\frac{\gamma}{\alpha(1-\gamma)+\gamma}\right]
$$

Now consider the relations $\Delta \theta_{\mathrm{t}}=\overline{\mathrm{r}}+\epsilon^{\mathrm{D}}, \Delta \tau_{\mathrm{t}}=\overline{\mathrm{g}}+\epsilon^{\mathrm{g}}, \Delta \ln \left(\mathrm{A}_{\mathrm{N}}\right)=\overline{\mathrm{y}}+\epsilon^{\mathrm{S}}$, and $\Delta \ln \left(\mu_{t}\right)=\bar{M}+\epsilon^{m}$. In order to derive equation (3), it is necessary to use these and to discuss two more aspects of the model. First, since equilibrium output is supply-determined, the preference shock $\epsilon^{\mathrm{D}}$, will not affect output in the long run. This implies the ordering of variables two and three. Also, allowing for non-optimizing government activities, the fiscal shock affects output, and implies the ordering of variables one and two [i.e., not imposing the over-identifying restriction $\mathrm{C}_{21}=0$ ]. 
Second, the final two equations in (3) are derived using equation (A13), which indicates that real money balances, $\mathrm{m}$, are a function of the fiscal, productivity, preference, and money growth shocks. Writing $\mathrm{m}=\mathrm{mm}+\mathrm{h}$, where $\mathrm{mm}$ is the log money multiplier and $\mathrm{h}$ is the log real monetary base, the ordering of variables four $(\Delta \mathrm{mm})$ and five $(\Delta \mathrm{h})$ reflects the assumption that shocks to the monetary base have a one-to-one effect on the money supply in the long-run.

Finally, two caveats are in order. First, replacing $\ln (\mathrm{Q})=\mathrm{p}_{\mathrm{N}}-\mathrm{p}_{\mathrm{T}}$ with $\mathrm{r}\left(=\mathrm{s}+\mathrm{p}^{*}-\mathrm{p}\right)$ implies a switch in the signs of $c_{21}$ and $c_{22}$ in going from (A18) to (3). Writing the home price index as $\mathrm{p}=\mathrm{ap}_{\mathrm{N}}+(1-\mathrm{a}) \mathrm{p}_{\mathrm{T}}$, and assuming an analogous expression for foreign prices, allows us to write $\mathrm{r}=\left(\mathrm{s}+\mathrm{p}_{\mathrm{T}}^{*}-\mathrm{p}_{\mathrm{T}}\right)-\mathrm{a}\left(\mathrm{p}_{\mathrm{N}}-\mathrm{p}_{\mathrm{T}}\right)+\mathrm{a}^{*}\left(\mathrm{p}_{\mathrm{N}}^{*}-\mathrm{p}_{\mathrm{T}}^{*}\right)$, and implies a negative relationship between $\mathrm{Q}$ and $\mathrm{r}$. Also note that the real exchange rate equation in (3) would be obtained if we considered an equation analogous to (A18) holds for a "foreign" country. If relative PPP holds for traded goods, so that $\left(\mathrm{s}+\mathrm{p}_{\mathrm{T}}^{*} \mathrm{p}_{\mathrm{T}}\right)$ is constant, this alternative two-country specification would imply an exact correspondence between Q (or "Q - Q"), which is used in the model, and $\mathrm{r}$, which is used in the empirical work.

Second, the signs of $\mathrm{c}_{21}$ and $\mathrm{c}_{22}$, the long-run effect of the fiscal shock and the supply shock on the real exchange rate, respectively, are unclear in theory. Equation (A6) indicates that in general the signs depend on whether the shocks have a larger effect on the consumption of traded or non-traded goods. This becomes somewhat hidden in the derivation of (3), because I have used (A16) to solve for traded goods consumption in terms of non-traded goods consumption, and hence have written the model in terms of the productivity shock in the non-traded goods sector and government consumption of nontraded goods (which is probably the more accurate choice, since most government spending is on nontradeables). That fiscal shocks have an ambiguous effect on the real exchange rate is a feature of several models.

\section{APPENDIX B: Identifying the VAR when the Real Exchange Rate is I(0)}

In this appendix I discuss the implications of switching from estimating the VAR when all of the variables are assumed to be $\mathrm{I}(1)$ to one in which one variable is assumed to be $\mathrm{I}(0)$. I demonstrate how to retrieve the desired structural MA representation from the underlying VAR, using two examples. The examples are kept simple for expositional purposes, but are readily generalized.

\section{Case 1. All variables are I(1)}

This is the familiar case, in which both $\mathrm{x}, \mathrm{y}$, and $\mathrm{z}$ are unit root processes:

(1a) $\mathrm{x}_{\mathrm{t}}=\alpha_{11} \mathrm{y}_{\mathrm{t}}+\alpha_{12} \mathrm{y}_{\mathrm{t}-1}+\beta_{12} \mathrm{x}_{\mathrm{t}-1}+\mathrm{c}_{11} \mathrm{z}_{\mathrm{t}}+\mathrm{c}_{12} \mathrm{z}_{\mathrm{t}-1}+\mathrm{u}_{1 \mathrm{t}}$ with random walk error term: $\Delta \mathrm{u}_{1 \mathrm{t}}=\epsilon_{1 \mathrm{t}}$,

(1b) $\mathrm{y}_{\mathrm{t}}=\alpha_{22} \mathrm{y}_{\mathrm{t}-1}+\beta_{21} \mathrm{x}_{\mathrm{t}}+\beta_{22} \mathrm{x}_{\mathrm{t}-1}+\mathrm{c}_{21} \mathrm{z}_{\mathrm{t}}+\mathrm{c}_{22} \mathrm{z}_{\mathrm{t}-1}+\mathrm{u}_{2 \mathrm{t}}$ with random walk error: $\Delta \mathrm{u}_{2 \mathrm{t}}=\epsilon_{2 \mathrm{t}}$.

(1c) $\mathrm{z}_{\mathrm{t}}=\mathrm{c}_{32} \mathrm{z}_{\mathrm{t}-1}+\alpha_{31} \mathrm{y}_{\mathrm{t}}+\alpha_{32} \mathrm{y}_{\mathrm{t}-1}+\beta_{31} \mathrm{x}_{\mathrm{t}}+\beta_{32} \mathrm{x}_{\mathrm{t}-1}+\mathrm{u}_{3 \mathrm{t}}$ with random walk error: $\Delta \mathrm{u}_{3 \mathrm{t}}=\epsilon_{3 \mathrm{t}}$.

Use the lag operator L to re-write the above, and then take first-differences:

$$
\begin{aligned}
& \left(1-\beta_{12} L\right) \Delta x_{t}=\left(\alpha_{11}+\alpha_{12} L\right) \Delta y_{t}+\left(c_{11}+c_{12} L\right) \Delta z_{t}+\epsilon_{1 t} \\
& \left(1-\alpha_{22} L\right) \Delta y_{t}=\left(\beta_{21}+\beta_{22} L\right) \Delta x_{t}+\left(c_{21}+c_{22} L\right) \Delta z_{t}+\epsilon_{2 t} \\
& \left(1-c_{32} L\right) \Delta z_{t}=\left(\alpha_{31}+\alpha_{32} L\right) \Delta y_{t}+\left(\beta_{31}+\beta_{32} L\right) \Delta x_{t}+\epsilon_{3 t}
\end{aligned}
$$


In the long run, with $\mathrm{L}=1$ :

(3a)

$$
\Delta \mathrm{x}_{\mathrm{t}}=\left[\left(\alpha_{11}+\alpha_{12}\right) /\left(1-\beta_{12}\right)\right] \Delta \mathrm{y}_{\mathrm{t}}+\left[\left(\mathrm{c}_{11}+\mathrm{c}_{12}\right) /\left(1-\beta_{12}\right)\right] \Delta \mathrm{z}_{\mathrm{t}}+\epsilon_{1 \mathrm{t}}
$$

$$
\Delta \mathrm{y}_{\mathrm{t}}=\left[\left(\beta_{21}+\beta_{22}\right) /\left(1-\alpha_{22}\right)\right] \Delta \mathrm{x}_{\mathrm{t}}+\left[\left(\mathrm{c}_{21}+\mathrm{c}_{22}\right) /\left(1-\alpha_{22}\right)\right] \Delta \mathrm{z}_{\mathrm{t}}+\epsilon_{2 \mathrm{t}}
$$$$
\Delta \mathrm{z}_{\mathrm{t}}=\left[\left(\alpha_{31}+\alpha_{32}\right) /\left(1-\mathrm{c}_{32}\right)\right] \Delta \mathrm{y}_{\mathrm{t}}+\left[\left(\beta_{31}+\beta_{32}\right) /\left(1-\mathrm{c}_{32}\right)\right] \Delta \mathrm{x}_{\mathrm{t}}+\epsilon_{3 \mathrm{t}}
$$

The three identifying restrictions in this familiar case are that the coefficients on (1) current and lagged $\mathrm{y}$ in equation (1a) sum to zero, $\alpha_{11}+\alpha_{12}=0$; (2) current and lagged $\mathrm{z}$ in equation (1a) sum to zero, $\mathrm{c}_{11}+\mathrm{c}_{12}=0$; (3) on current and lagged $\mathrm{z}$ in equation (1b) sum to zero, $\mathrm{c}_{21}+\mathrm{c}_{22}=0$. These zero restrictions give us the desired structural MA representation of the reduced-form VAR:

(4a) $\Delta \mathrm{x}_{\mathrm{t}}=\epsilon_{1 \mathrm{t}}$

(4b) $\Delta \mathrm{y}_{\mathrm{t}}=\lambda \epsilon_{1 \mathrm{t}}+\epsilon_{2 \mathrm{t}}$

(4c) $\Delta \mathrm{z}_{\mathrm{t}}=\phi \epsilon_{1 \mathrm{t}}+\delta \epsilon_{2 \mathrm{t}}+\epsilon_{3 \mathrm{t}}$

where $\lambda=\left[\left(\beta_{21}+\beta_{22}\right) /\left(1-\alpha_{22}\right)\right], \phi=\left[\left(\beta_{31}+\beta_{32}\right) /\left(1-c_{32}\right)\right]+\lambda$, and $\delta=\left[\left(\alpha_{31}+\alpha_{32}\right) /\left(1-c_{32}\right)\right]$.

Economically, the identifying assumptions are that shocks to $\mathrm{z}$ have no effect on the level of $\mathrm{x}$ or $y$ in the long run, and that shocks to $y$ have no effect on the long-run level of $x$. On the other hand, the long-run level of $\mathrm{z}$ is allowed to be affected by all shocks, while the long-run level of $\mathrm{y}$ is affected by shocks to $\mathrm{x}$ only.

\section{Case 2. The "middle" variable $y$, is $I(0)$}

Consider the case in which one of the variables is $\mathrm{I}(0)$. Choose $\mathrm{y}$, since that is neither the first nor last variable, just like my example in the text. The crucial difference between this case and Case 1 is that the underlying VAR must be set up along the lines of the following:

$$
\begin{aligned}
& \text { (5a) } \mathrm{x}_{\mathrm{t}}=\alpha_{11} \mathrm{y}_{\mathrm{t}}+\alpha_{12} \mathrm{y}_{\mathrm{t}-1}+\beta_{12} \mathrm{x}_{\mathrm{t}-1}+\mathrm{c}_{11} \mathrm{z}_{\mathrm{t}}+\mathrm{c}_{12} \mathrm{z}_{\mathrm{t}-1}+\mathrm{u}_{1 \mathrm{t}} \\
& \text { (5b) } \mathrm{y}_{\mathrm{t}}=\alpha_{22} \mathrm{y}_{\mathrm{t}-1}+\beta_{21} \Delta \mathrm{x}_{\mathrm{t}}+\beta_{22} \Delta \mathrm{x}_{\mathrm{t}-1}+\mathrm{c}_{21} \Delta \mathrm{z}_{\mathrm{t}}+\mathrm{c}_{22} \Delta \mathrm{z}_{\mathrm{t}-1}+\epsilon_{2 \mathrm{t}} \\
& \text { (5c) } \mathrm{z}_{\mathrm{t}}=\alpha_{31}\left(\mathrm{y}_{\mathrm{t}}+\mathrm{y}_{\mathrm{t}-1}+\mathrm{y}_{\mathrm{t}-2}+\ldots\right)+\mathrm{y}_{0}+\beta_{31} \mathrm{x}_{\mathrm{t}}+\beta_{32} \mathrm{x}_{\mathrm{t}-1}+\mathrm{c}_{31} \mathrm{z}_{\mathrm{t}}+\mathrm{c}_{32} \mathrm{z}_{\mathrm{t}-1}+\mathrm{u}_{3 \mathrm{t}}
\end{aligned}
$$

i.e., such that an infinite sum of lagged $\mathrm{y}_{\mathrm{t}}$ 's appears in the reduced form equation for $\mathrm{z}$, and that firstdifferences of $\mathrm{x}$ and $\mathrm{z}$ appear in the reduced-form equation for $\mathrm{y}$.

To see how the desired structural MA representation is retrieved from the underlying VAR, rewrite equations (5) using the lag operator L:

(6a) $\left(1-\beta_{12} L\right) x_{t}=\left(\alpha_{11}+\alpha_{12} L\right) y_{t}+\left(c_{11}+c_{12} L\right) z_{t}+u_{1 t}$

(6b) $\left(1-\alpha_{22} \mathrm{~L}\right) \mathrm{y}_{\mathrm{t}}=\left(\beta_{21}+\beta_{22} \mathrm{~L}\right) \Delta \mathrm{x}_{\mathrm{t}}+\left(\mathrm{c}_{21}+\mathrm{c}_{22} \mathrm{~L}\right) \Delta \mathrm{z}_{\mathrm{t}}+\epsilon_{2 \mathrm{t}}$

(6c) $\left(1-c_{32} L\right) z_{t}=\left(1+L+L^{2}+\ldots\right) \alpha_{31} y_{t}+y_{0}+\left(\beta_{31}+\beta_{32} L\right) x_{t}+u_{3 t}$

$$
=(1-L)^{-1} \alpha_{31} y_{t}+y_{0}+\left(\beta_{31}+\beta_{32} L\right) x_{t}+u_{3 t}
$$


In order to obtain a stationary representation, first-difference equations (6a) and (6c). Then re-arrange, ignoring the multiplicative constant term on the error terms, and set $\mathrm{L}=1$, to get:

(7a) $\Delta \mathrm{x}_{\mathrm{t}}=\left[\left(\alpha_{11}+\alpha_{12}\right) /\left(1-\beta_{12}\right)\right] \Delta \mathrm{y}_{\mathrm{t}}+\left[\left(\mathrm{c}_{11}+\mathrm{c}_{12}\right) /\left(1-\beta_{12}\right)\right] \Delta \mathrm{z}_{\mathrm{t}}+\epsilon_{1 \mathrm{t}}$

(7b) $y_{t}=\left[\left(\beta_{21}+\beta_{22}\right) /\left(1-\alpha_{22}\right)\right] \Delta x_{t}+\left[\left(c_{21}+c_{22}\right) /\left(1-\alpha_{22}\right)\right] \Delta z_{t}+\epsilon_{2 t}$

(7c) $\Delta \mathrm{z}_{\mathrm{t}}=\left[\left(\beta_{31}+\beta_{32}\right) /\left(1-\mathrm{c}_{32}\right)\right] \Delta \mathrm{x}_{\mathrm{t}}+\left[\alpha_{31} /\left(1-\mathrm{c}_{32}\right)\right] \mathrm{y}_{\mathrm{t}}+\epsilon_{3 \mathrm{t}}$

Equations (7) reduce to the desired MA representation when three identifying restrictions are imposed: $\alpha_{11}+\alpha_{12}=0 ; c_{11}+c_{12}=0$; and $c_{21}+c_{22}=0$. That MA representation is of the form:

(8a) $\Delta x_{t}=\epsilon_{1 \mathrm{t}}$

$$
y_{t}=\rho \epsilon_{1 t}+\epsilon_{2 t}
$$

(8c) $\Delta \mathrm{z}_{\mathrm{t}}=\tau \epsilon_{1 \mathrm{t}}+\omega \epsilon_{2 \mathrm{t}}+\epsilon_{3 \mathrm{t}}$

Notice that these zero restrictions are identical to those used in Case 1 above. In this case, the restriction that "zeroes out" the long-run effect of $\epsilon_{3 \mathrm{t}}$ in the first equation (i.e., $\mathrm{c}_{11}+\mathrm{c}_{12}=0$ ) still implies that shocks to $\mathrm{z}$-- think of $\mathrm{z}$ as money -- have no long-run effect on the level of $\mathrm{x}_{\mathrm{t}}$. Notice that no shocks have a permanent effect on the level of $y_{t}$, which is a direct implication of our assumption that $y$ is stationary. However, the restriction that "zeroes out" the long-run effect of $\epsilon_{3 \mathrm{t}}$ in the equation for $\mathrm{y}$ (i.e., $\mathrm{c}_{21}+\mathrm{c}_{22}=$ 0 ) now means that shocks to $\mathrm{z}$ have no long-run effect on the accumulated level of $\mathrm{y}_{\mathrm{t}}$. Unlike the economic interpretation of this restriction for Case 1 (i.e., shocks to $\mathrm{z}$ have no long-run effect on the level of $y_{t}$ ), this is likely to no longer have a basis in theory.

Thus, as discussed in the text, I use Case 3:

\section{Case 3. Place the Stationary Variable last in the Ordering:}

Call the $\mathrm{I}(0)$ variable $\mathrm{y}$ again, so the ordering now becomes $\{\mathrm{x}, \mathrm{z}, \mathrm{y}\}$. The formal identification restrictions follow directly from the above examples, and so are skipped here. The economic interpretation of the restrictions is analogous to that in the text for my five-variable model: (I) none of the shocks has a permanent effect on the level of $y_{t}$, (ii) $\epsilon_{3 t}$, the shock to $y$, is a transitory disturbance and so has no long-run effect on the level of any variable, and (iii) just as in the cases above, shocks to z have no long-run effect on the level of $\mathrm{x}_{\mathrm{t}}$. 
Table A-1: LR Tests for Lag Length in the 5-Variable VAR with Long-Term U.S.-U.K. Data

\begin{tabular}{|c|c|c|c|c|c|c|c|c|}
\hline $\begin{array}{l}\text { Lags / } \\
\text { LR-stat }\end{array}$ & 9 vs. 8 & 8 vs. 7 & 7 vs. 6 & 6 vs. 5 & 5 vs. 4 & 4 vs. 3 & 3 vs. 2 & 2 vs. 1 \\
\hline Case 1 & $\begin{array}{c}33.7 \\
(0.11)\end{array}$ & $\begin{array}{c}51.0 \\
(0.001)\end{array}$ & $\begin{array}{c}19.8 \\
(0.75)\end{array}$ & $\begin{array}{c}31.9 \\
(0.16)\end{array}$ & $\begin{array}{c}43.1 \\
(0.01)\end{array}$ & $\begin{array}{c}30.8 \\
(0.20)\end{array}$ & $\begin{array}{c}25.0 \\
(0.46)\end{array}$ & $\begin{array}{c}71.7 \\
(0.00)\end{array}$ \\
\hline Case 2 & $\begin{array}{c}45.2 \\
(0.001)\end{array}$ & $\begin{array}{c}38.1 \\
(0.045)\end{array}$ & $\begin{array}{c}25.9 \\
(0.42)\end{array}$ & $\begin{array}{c}23.2 \\
(0.57)\end{array}$ & $\begin{array}{c}27.4 \\
(0.34)\end{array}$ & $\begin{array}{c}40.1 \\
(0.03)\end{array}$ & $\begin{array}{c}19.7 \\
(0.76)\end{array}$ & $\begin{array}{c}55.1 \\
(0.00)\end{array}$ \\
\hline
\end{tabular}

Notes: LR denotes the likelihood ratio statistic used to test the null hypothesis that the $\mathrm{j}+1$ lags in each VAR equation are zero. The marginal significance level of the LR statistic is in parenthesis. In case 1, the system variables are: $(\mathrm{G} / \mathrm{Y}), \mathrm{y}, \mathrm{r} 2, \mathrm{~mm}, \mathrm{~h}$. In case 2 , the system variables are: $(\mathrm{G} / \mathrm{Y}), \mathrm{y}, \mathrm{r} 3, \mathrm{~mm}, \mathrm{~h}$.

Table A-2: Tests of Cointegrating Rank in the 5-Variable VAR with Long-Term U.S.-U.K. Data

\begin{tabular}{|c|c|c|c|c|c|c|c|}
\hline \multirow{2}{*}{$\begin{array}{l}\mathrm{H}_{0}: \mathrm{CI} \\
\text { rank=p }\end{array}$} & \multicolumn{3}{|c|}{ Trace stat. (r2 model) } & \multicolumn{3}{|c|}{ Trace stat. (r3 model) } & \multirow{2}{*}{$\begin{array}{c}95 \% \text { critical } \\
\text { value } \\
\end{array}$} \\
\hline & 8 lags & 5 lags & 2 lags & 8 lags & 4 lags & 2 lags & \\
\hline $\mathrm{p}=0$ & 48.7 & 63.7 & 54.9 & 52.7 & 50.3 & 57.6 & 68.5 \\
\hline $\mathrm{p} \leq 1$ & 24.2 & 29.0 & 25.7 & 25.2 & 27.2 & 31.6 & 47.2 \\
\hline $\mathrm{p} \leq 2$ & 13.9 & 14.4 & 13.3 & 14.9 & 9.41 & 11.3 & 29.7 \\
\hline $\mathrm{p} \leq 3$ & 6.10 & 5.07 & 4.01 & 6.92 & 3.29 & 4.24 & 15.4 \\
\hline $\mathrm{p} \leq 4$ & 0.24 & 0.32 & 0.08 & 0.15 & 0.04 & 0.28 & 3.8 \\
\hline
\end{tabular}

Notes: As in table 3, the trace statistics apply a simple small-sample correction to Johansen's (1991) statistics. The system variables are: (G/Y), y, r2, mm, and $\mathrm{h}$ in the "r2 model" case, and (G/Y), y, r3, $\mathrm{mm}$, and $\mathrm{h}$ in the " $\mathrm{r} 3$ model" case. The sample period is 1889-1992. Lag length in the VAR is displayed in the top row. 


\section{Figure 1. Variables in the VAR-Levels}
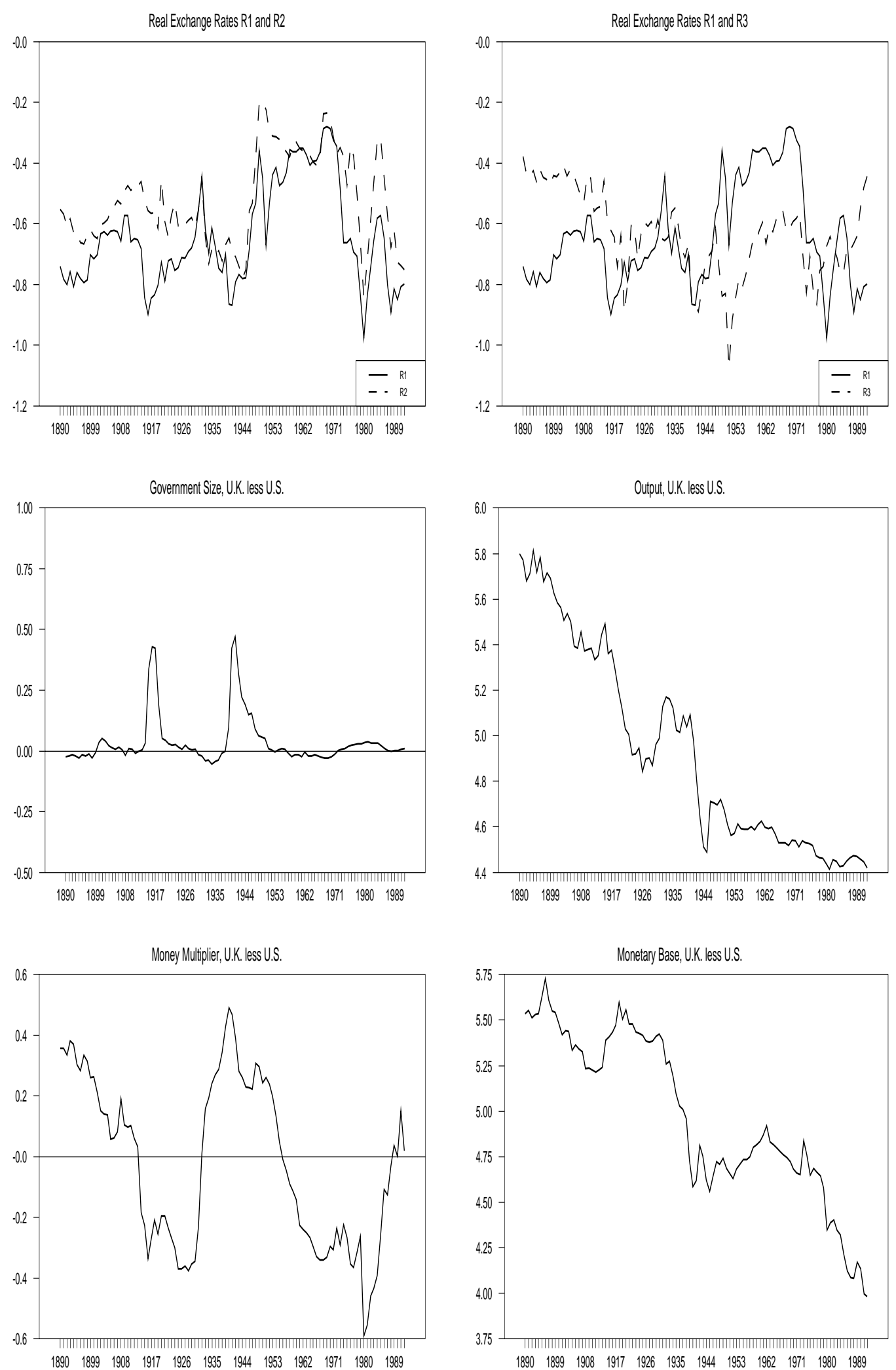
Figure?

Plots of the Structural Disturbances
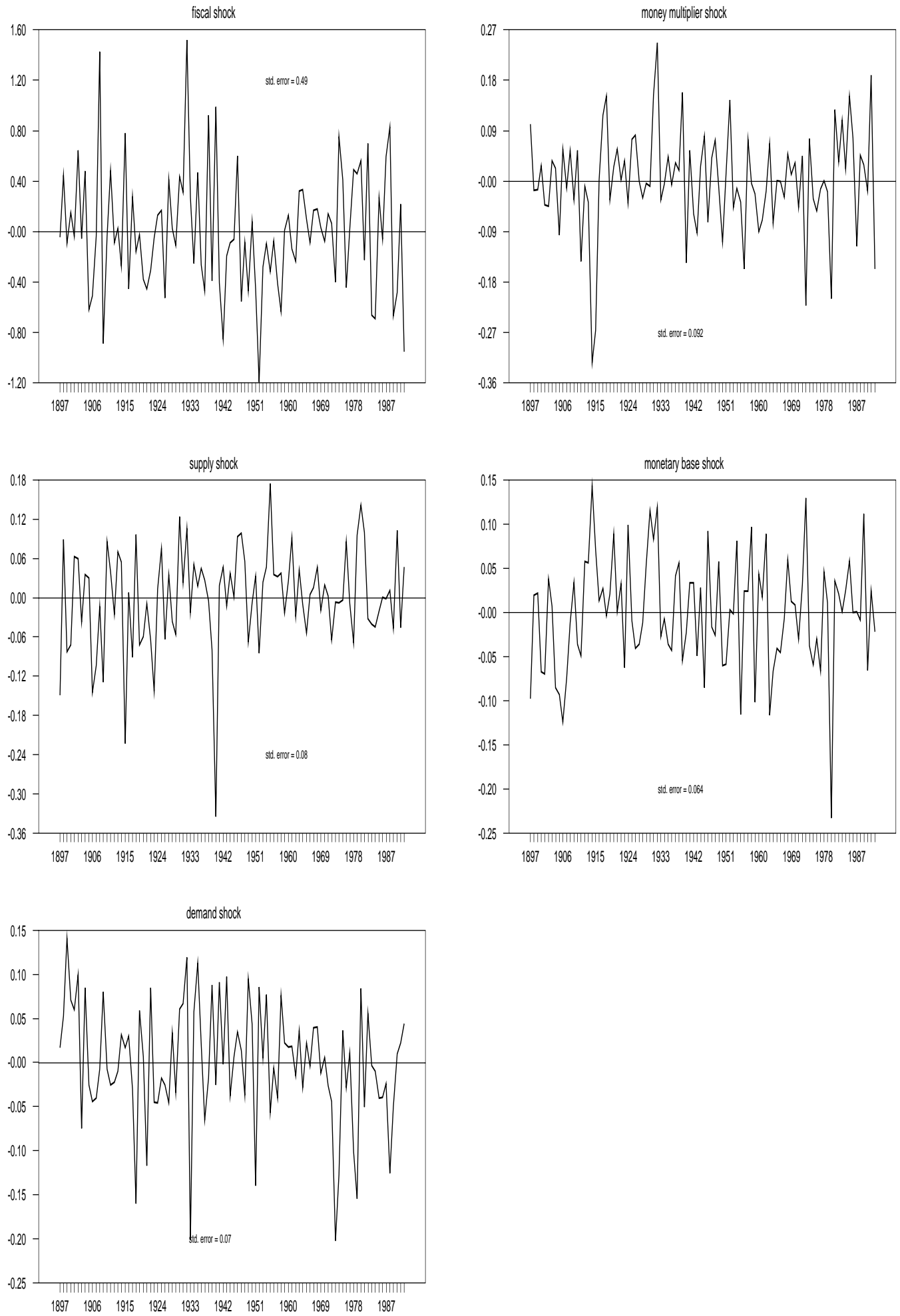
Figure 3

Impulse Responses, Baseline Model with Long-Run Restrictions

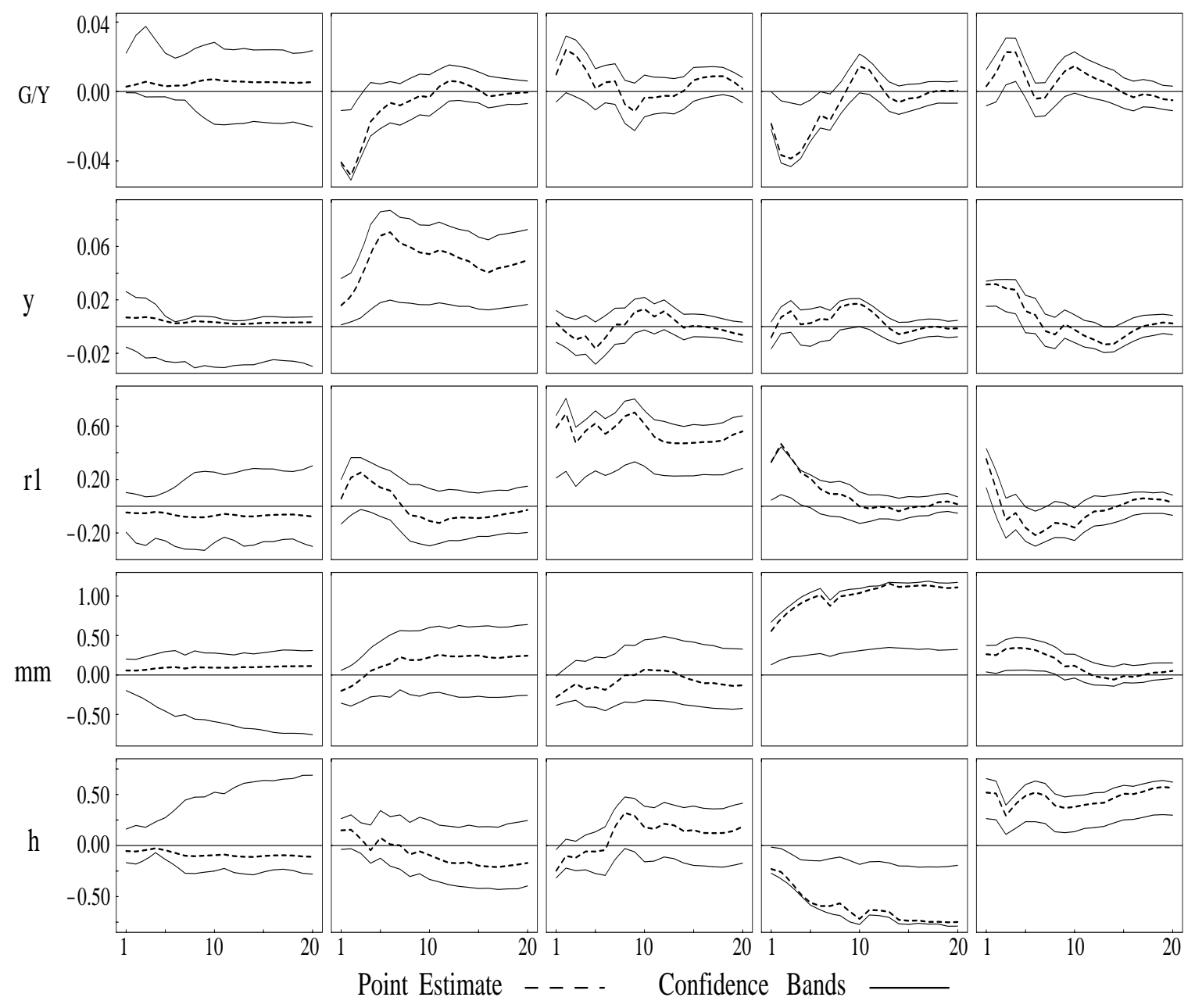


Figure 4

\section{Impulse Responses, Baseline Model with Short-Run Restrictions}

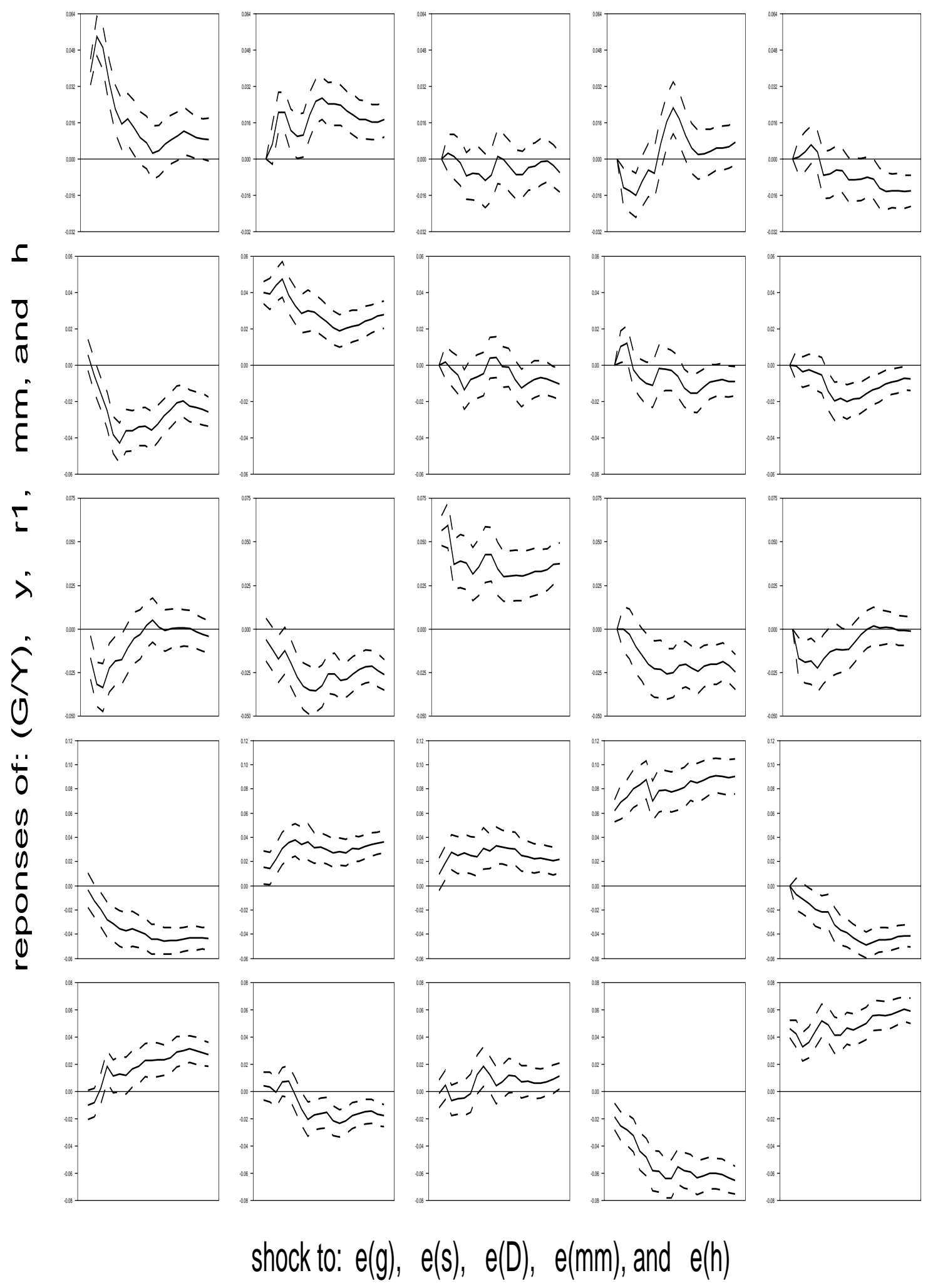




\section{Figure 5. Levels of the Variables in the VARs - CG Sample}

(right scale - Canada, left scale - U.K.)
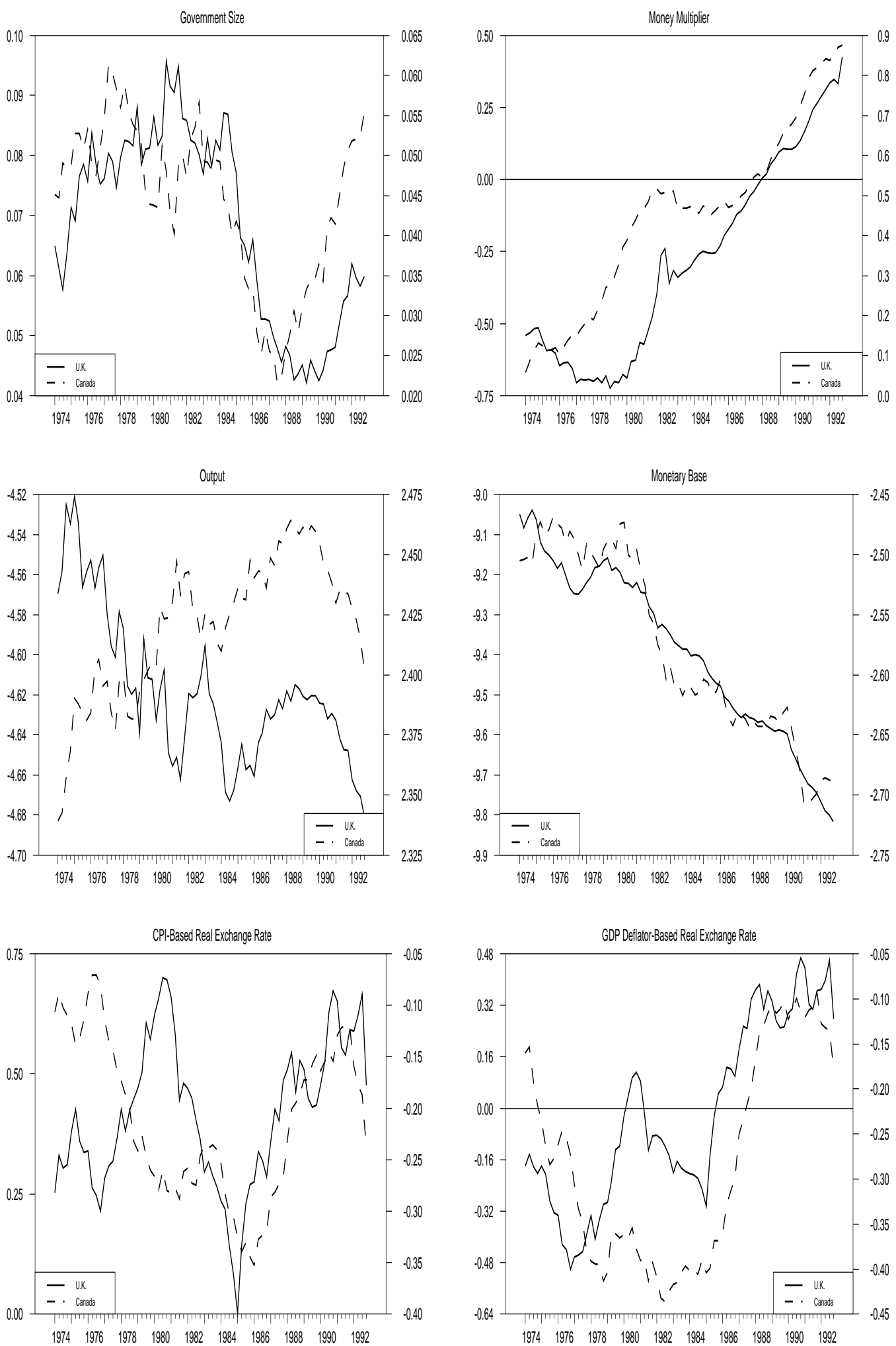